This item was submitted to Loughborough's Research Repository by the author.

Items in Figshare are protected by copyright, with all rights reserved, unless otherwise indicated.

\title{
Landfill side slope lining system performance: a comparison of field measurements and numerical modelling analyses
}

PLEASE CITE THE PUBLISHED VERSION

http://dx.doi.org/10.1016/j.geotexmem.2014.03.003

\section{PUBLISHER}

(c) Elsevier

\section{VERSION}

AM (Accepted Manuscript)

\section{PUBLISHER STATEMENT}

This work is made available according to the conditions of the Creative Commons Attribution-NonCommercialNoDerivatives 4.0 International (CC BY-NC-ND 4.0) licence. Full details of this licence are available at: https://creativecommons.org/licenses/by-nc-nd/4.0/

\section{LICENCE}

CC BY-NC-ND 4.0

\section{REPOSITORY RECORD}

Zamara, Katarzyna A., Neil Dixon, Gary Fowmes, D. Russell V. Jones, and Bo Zhang. 2014. "Landfill Side Slope Lining System Performance: A Comparison of Field Measurements and Numerical Modelling Analyses". Loughborough University. https://hdl.handle.net/2134/18338. 
1 Landfill side slope lining system performance: A comparison of field measurements and

2 numerical modelling analyses

3 Katarzyna A. Zamara

4 CICE, School of Civil and Building Engineering, Loughborough University LE11 3TU, UK

5 \& FCC Environment Ltd Ground Floor West, 900 Pavilion Drive, Northampton, NN4 7RG

$6 \quad$ Katarzyna.Zamara@FCCEnvironment.co.uk

7 Neil Dixon \& Gary Fowmes

8 School of Civil and Building Engineering, Loughborough University, LE11 3TU, UK.

$9 \quad$ N.Dixon@lboro.ac.uk

10 D. Russell V. Jones \& Bo Zhang

11 Golder Associates (UK) Ltd Nottingham, NG12 5BL, UK. R.Jones@golder.com

Abstract

Low permeability engineered landfill barriers often consist of a combination of geosynthetics

15 and mineral layers. Even though numerical modelling software is applied during the landfill design process, a lack of data about mechanical performance of landfill barriers is available to

17 validate and calibrate those models. Instrumentation has been installed on a landfill site to monitor multilayer landfill lining system physical performance. The lining system comprises of a compacted clay layer overlaid by high density polyethylene geomembrane, geotextile and sand.

Data recorded on the site includes: geosynthetic displacements (extensometers), strains (fibre optics, Demec strain gauges, extensometers) and stresses imposed on the liner (pressure cells). In

22 addition, temperature readings were collected by a logger installed at the surface of the geomembrane, at the clay surface using pressure cell thermistors and air temperature using a thermometer. This paper presents readings collected throughout a period of three years and compares this measured performance with the corresponding numerical modelling of the lining system for stages during construction. Numerical modelling predictions of lining system

27 behaviour during construction are comparable with the measurements when the geosynthetics are 
29 extended period of time, in situ behaviour of the geosynthetics cannot be replicated by the numerical analysis. This study highlights the significant influence of the effect of temperature on geosynthetics displacements. A simple thermal analysis of the exposed geosynthetics is used to support the explanation for observed behaviour.

Key words: landfill lining system, geosynthetics, monitoring, numerical modelling.

Geosynthetics are materials that have been widely used in the construction industry for decades. More importantly, they have been recognised as a suitable material for waste barriers and have

37 become extensively applied in landfill engineering. Even though their in situ mechanical

38 behaviour has not been fully measured or defined, experience gained through multiple applications and ease of installation has resulted in their acceptance by regulatory agencies,

40 designers and contractors. For over two decades geosynthetic interface shear strength has been a 41 subject of investigations throughout the world. Dixon et al. (2006) present data from 76 sources

42 of interfaces commonly deployed in landfills. Furthermore, developed methods of measurement,

43 the procedures and variability in obtainable results are still the subject of many on-going

44 discussions. To consider the complex nature of material behaviour and their interactions, landfill 45 design methods incorporating geosynthetic materials can take the form of limit equilibrium or 46 advanced numerical modelling analyses. The latter are often used for more complicated design

47 cases, where the in situ conditions are not favourable and/or serious environmental implications 48 would result from failure. Even though the number of designs based on numerical modelling has 49 increased in recent years, very limited field data on in service performance of lining systems 50 exists to allow validation of models in order to confirm their accuracy and suitability. Often, 51 model verifications are based on analysis of landfill failures (Koerner and Soong 2000, Dixon 
52 and Jones 2003, Muhsiung 2005) but these cannot deliver data on in service performance of the

53 materials and composite lining systems such as: displacements, strains or tensile stresses in

54 geosynthetic components resulting from overburden pressures, process of waste placement

55 during landfill cell filling and long term degradation of the waste body. Therefore, lining system

56 stability (ultimate limit state related to large scale movements) and integrity (serviceability limit

57 state - overstressing of liner elements and subsequently loss of original functions) in terms of

58 construction safety, optimal and reliable design (accurate prediction of imposed stresses,

59 evaluation of strains and axial forces within geosynthetics) are still topics of research.

60

61 Since only limited information exists on in situ geosynthetic performance in the landfill

62 environment, the need for numerical model validation and calibration is self-evident. Dixon et al.

63 (2012) summarises the current state of research on lining system stability and integrity, and

64 emphasises common engineering problems related to geosynthetics in the landfill environment

65 (i.e. staged construction, strain softening interfaces, progressive failure, tensile stresses in

66 materials, representation of waste parameters and behaviour, ageing and waste biodegradation).

67 The purpose of the study reported by Dixon et al. (2012) was to investigate interface strain

68 softening design issues, as often interfaces between materials installed on landfill slopes

69 (geosynthetics/geosynthetics, geosynthetics/soil) reveal strain softening behaviour (i.e. the

70 interface shear strength decreases to residual large displacement values after reaching its peak).

71 Studies have been carried out to investigate these phenomena, to incorporate these aspects in

72 numerical analyses (e.g. Arab 2011, Sia \& Dixon 2012, Fowmes et al. 2005) and some limited

73 number of physical experiments have been carried out (e.g. Villard et al.1999, Fowmes et al.

74 2008). However data to verify actual in situ behaviour of lining components and their interfaces

75 when subject to staged construction and waste settlement is still inadequate. 
77 This paper presents results from a three year full scale investigation of mechanical performance

78 of a multi-layered landfill lining system, carried out at the Milegate Extension Landfill, UK. The

79 lining system comprises a compacted clay layer, overlaid by geomembrane, geotextile and a sand

80 layer. The project started in June 2009 and monitoring was carried out for the following 3 years.

81 Instrumentation installed on the site consists of pressure cells (PC), extensometers (Ext), fibre

82 optic strain gauges (FO), Demec strain gauges (DSG) and additionally thermometers.

83

84 This paper aims to provide improved understanding of lining system in situ behaviour and to

85 highlight factors that influence interface mobilised strength and geosynthetic strains. A

86 numerical model representing the configuration and construction sequence of a side slope at the

87 Milegate landfill, was created to validate and calibrate the numerical modelling design approach.

88 Numerical analyses were undertaken using FLAC software and the results compared with the

89 measured in situ behaviour of the lining system materials. Analyses were carried out to replicate

90 common design conditions including staged construction, a multiple mineral/geosynthetic lining

91 system with associated multiple strain softening interfaces, and waste body compression during

92 filling under self-weight.

93

942 MILEGATE EXTENSION LANDFILL STUDY CASE

95 Details regarding the site monitored such as: slope geometry, instrumentation and its

96 performance, installed lining materials and history of construction works undertaken are reported

97 by Zamara et al. (2012). Only a brief description of the main aspects of the site works is

98 reported below as an introduction. 
100

101

102

103

104

105

106

107

108

109

110

111

112

113

114

115

116

117

118

119

120

121

122

123

\subsection{The trial site}

The monitored slope has a length of $31.2 \mathrm{~m}$ and height of $16 \mathrm{~m}$ with an inclination angle of $1 \mathrm{v}: 2.5 \mathrm{~h}\left(\sim 21.8^{\circ}\right)$. Figure 1 shows the site location, slope geometry and photographs of initial and one of the final waste placement stages. The lining system deployed was placed in addition to the pre-existing clay liner, and therefore is an additional and hence sacrificial layer that does not form part of the approved containment system at this site. The combination of materials forming the lining system was: clay, geomembrane, geotextile and a veneer of soil, which were chosen to represent common practice.

\subsection{Materials}

The instrumented lining system comprised of a $2 \mathrm{~mm}$ double textured HDPE geomembrane $5 \mathrm{~m}$ wide panel, with density of $0.949 \mathrm{~g} / \mathrm{cm}^{3}$ (GM TMT from Atarfil S.L.) placed on top of the compacted $1.0 \mathrm{~m}$ thick clay liner with a maximum permeability of $1 \times 10^{-9} \mathrm{~m} / \mathrm{s}$. The geomembrane was overlain by a non-woven needle punched geotextile $5 \mathrm{~m}$ wide panel. This protection layer has a static puncture strength [CBR] of $14 \mathrm{kN}$, thickness of $7.8 \mathrm{~mm}$ and weight of $1400 \mathrm{~g} / \mathrm{m}^{2}$ (HPS14 from GeoFabrics Ltd.). The multilayered landfill system is shown schematically in Figure 2. The geomembrane and geotextile were anchored in a "U” shaped $600 \mathrm{~mm} \times 600 \mathrm{~mm}$ anchor trench at the top of the slope. The geomembrane/geotextile “experimental” panel replaced the existing geocomposite drainage material over a slope width of $5.0 \mathrm{~m}$. A nominally $0.5 \mathrm{~m}$ thick sand veneer was placed in stages on the geotextile ahead of waste placement. This represents common practice of providing a mineral drainage layer on side slopes. Prior to waste placement the sand layer was placed in lifts parallel to the slope along 10 $\mathrm{m}$ of slope length. When the waste body reached the top of the first veneer a second $10 \mathrm{~m}$ sand layer measured parallel to the slope was placed along the slope. When the waste reached the top of the second veneer layer a third and last veneer lift was constructed and the whole length of the 
124 slope was then covered with a $0.5 \mathrm{~m}$ thick sand layer. Placement of the sand veneers provided an 125 opportunity to measure response of the underlying geosynthetic components to the applied load.

126 In practice sand is not used for drainage layers due to its fine grading, relatively low permeability

127 and susceptibility to clogging but it was used in this study to produce loading equivalent to

128 gravel typically used for mineral drainage layers.

\subsection{Summary of instrumentation}

130 Instrumentation was designed to measure parameters that are the most important for the design

131 process and hence long term performance of the lining system. The instrumentation delivers

132 information about stresses imposed on the liner (three pressure cells along the slope at the clay/

133 geomembrane interface), displacements of the geosynthetic liner elements and relative

134 displacement between the liner elements (extensometers located on the geomembrane and

135 geotextile), strains in the geomembrane (measured using Demec strain gauges, Fibre optic cables

136 and calculated from extensometers) and geotextile strains (calculated from extensometers).

137 Figure 3 presents the schematic location of the instruments along the slope, and Table 1 details

138 the type, number and measured parameters of instrumentation installed on the site. Full details of 139 the instrumentation selection, installation and operation is provided by Zamara et al. (2012)

\section{MILEGATE EXTENSION LANDFILL NUMERICAL MODELLING}

142 One of the main aims of the study was to validate the numerical modelling results for

143 performance of the lining system during construction and waste placement against measured in

144 situ behaviour of the lining system. It was planned to fill the cell where the monitored slope was

145 located with waste within 1-2 years after the instrumentation installation, however this process

146 was delayed due to the current economic situation, which resulted in slower filling rates and

147 hence prolonged exposure of the lining materials to atmospheric conditions. 


\subsection{Finite Difference Computer Software}

A commercial software program FLAC (Itasca International Inc.) was used to compute predicted behaviour of lining materials and interfaces on the monitored landfill slope. FLAC has been used in several previous landfill geotechnical engineering studies (e.g. Fowmes et al. 2005, Arab 2011, Sia \& Dixon 2012). The code allows materials that undergo large strains to be modelled, and hence it is appropriate for use in studies of landfill construction processes. It can represent waste body deformation, interface displacement and geosynthetic strains. FLAC analyses reported in this paper were based on a landfill design procedure developed by Fowmes et al. (2007).

\subsection{The Landfill Model Geometry - general}

The model was built to represent the major aspects of the cell construction and waste filling process. The cell was formed from a clay layer modelled at the cell slope and base. The model allowed representation of staged construction of each sand veneer stage ( $0.5 \mathrm{~m}$ thick sand veneer was placed in 3 lifts, in $10 \mathrm{~m}$ long layers measured parallel to the slope), followed by 4 waste lifts. In total the model computes 16 stages of material placement (1st clay, 2nd sand veneer, 36th waste lifts, 7th sand veneer, 8-11th waste lifts, 12th sand veneer, 13-16th waste lifts). Each waste lift has a vertical thickness of approximately $1 \mathrm{~m}$.

\subsection{Multilayer lining system}

The geosynthetic lining elements were placed along the clay slope. Since the in situ material comprised of well compacted clay over a strata with high strength and stiffness properties, clay behaviour was not monitored and for the modelling approach it was considered to provide a stable foundation for the lining system. It should be noted that initially high stiffness values were assumed for the clay (150 MPa) as no movement was expected within the compacted clay layer, however, in further sensitivity analyses the clay stiffness was reduced to investigate the influence 
172 on geomembrane displacements (50 MPa). The geosynthetics were modelled as elastic beam

173 elements anchored at the top of the slope. Three interfaces between lining components were

174 assigned: clay/geomembrane, geomembrane/geotextile, geotextile/sand, and additionally the

175 sand/waste interface was given waste properties. Information on geosynthetic tensile behaviour

176 was provided by the suppliers of the materials: geomembrane thickness was $2 \mathrm{~mm}$ and Young

177 secant modulus E= $338 \mathrm{MPa}$ (for 5\% strain), geotextile thickness was $7.8 \mathrm{~mm}$ and Young

178 modulus E=120 MPa (for 5\% strain). Geosynthetics were not expected to fail through excessive

179 tensile deformations (latterly proven by both field measurements and results from the analyses),

180 therefore secant modulus values for 5\% strain were used to generate conservative strains.

181 Soil and waste materials where represented by Mohr -Coulomb failure criterion and the

182 properties assigned to the materials are given in Table 2. Waste properties are based on data

183 available from the literature (Jones \& Dixon 2005).

$184 \quad 3.4$ Interfaces

185 The importance of interface strength parameters has been emphasised previously by various 186 authors (e.g. Filz et al. 2001, Jones \& Dixon 2005). In general it is accepted that landfill side

187 slope lining systems might undergo interface shear strength softening behaviour and therefore 188 the Milegate model in FLAC incorporated strain softening interfaces between each lining 189 element. Interface shear strengths for each combination of materials were measured in a direct 190 shear box machine in a laboratory test programme and used in the numerical analyses (Table 3).

191 For each interface tests were carried out with five different normal stresses: 10, 25, 50, 100 and $192200 \mathrm{kPa}$. In order to acquire detailed information on the interfaces, tests were carried out with the 193 following conditions: dry interfaces (soil/geotextile, geotextile/geomembrane,

194 geomembrane/clay), submerged interfaces (soil/geotextile, geotextile/geomembrane), and slow 
195 displacement rate in an attempt to reflect drained conditions (geomembrane/clay). Each test was 196 repeated at least three times using new materials. Waste/soil interface properties were not

197 investigated in the laboratory and the values used are based on the common approach of 198 assigning the waste material properties to its interface with the granular drainage layer. In 199 addition, a key element of the model was the availability of strain softening interface behaviour 200 following the approach developed by Fowmes et al. (2007).

\subsection{The modelling process}

203 The most comprehensive and consistent site data was delivered from the extensometer

204 measurements of geomembrane and geotextile displacements, hence the first attempts to 205 compare numerical modelling outputs with the site data were initially focused on geosynthetic 206 displacements and the numerical model was then developed in an iterative process. One by one 207 sub-procedures were added to the basic model and examined in terms of generated geosynthetic 208 displacements during construction and waste placement. In the study four different interface 209 shear strength property scenarios were investigated: peak, residual, strain softening and reduced 210 values in an attempt to replicate the measured material displacements. Additionally, stiffness

211 values for the clay liner, geotextile and sand were reduced systematically in an attempt to 212 reproduce monitored lining system behaviour. These reduced values could be justified as 213 resulting from potential material and interface degradation processes.

\subsection{Stresses imposed on the liner}

217 Computed values of pressures imposed on the liner are within the ranges recorded on the site 218 using pressure cells (Figure 4). It can be concluded that stresses imposed on the side slope lining 
219 system, from waste unit weight and sand veneer can be represented by the numerical model.

220 Time has not been explicitly considered in the numerical analysis but stages of construction are

221 defined. The reference point for the plotted, measured and modelled values is the waste height

222 above the landfill base. The site records have been plotted against time to provide the time

223 framework for this study and to present the cell filling time-line.

224 The two lower pressure cells included thermistors measuring temperature at the clay surface

225 (Figure 3 PC24, PC30) and this facilitated temperature correction of the pressure cell readings,

226 which are plotted in Figure 4. It can be noticed that once the pressure cells were covered with

227 waste, temperatures on the clay surface show significantly less variation, and winter clay

228 temperatures did not decrease significantly from summer values.

2294.2 Geosynthetic deformations from extensometer readings vs. modelling predictions

230 Figure 5 presents an overview of all the displacements recorded by extensometers attached to the 231 geomembrane and geotextile throughout the three year construction and waste filling period.

232 Additionally, Table 4 summarises the maximum displacements of the geomembrane and 233 geotextile computed for various configurations of in-put parameters; Displacement values 234 recorded on the site are included in Table 4 for comparison.

235 4.2.1 Geotextile behaviour

236 Significant movements of the geotextile were recorded. Extensometers located within the middle 237 and upper parts on the slope recorded displacement up to $80 \mathrm{~mm}$ down slope. These large 238 movements were triggered mostly at the time of the second sand veneer placement. It can be 239 observed that site measurements show less consistent (along the slope) and more localised 240 displacements than the computed simulations. 
241 Results from the series of FLAC analyses are compared with the measured behaviour in Figures

2425 to 8 . The simulation labelled "MIN" uses input parameters that give the lowest displacements

243 of the lining components. These simulations were undertaken using a basic model with interfaces

244 described with either peak or residual shear strength properties (i.e. the interfaces are not strain

245 softening). Computed results using peak and residual interface strengths were comparable as

246 peak strength was not exceeded along the interface. "MAX" uses worst (i.e. lowest) credible

247 interface shear strength properties and reduced clay stiffnesses - assuming softening of clay after

248 placement on the slope. Using these parameters, unsurprisingly, computed displacements are the

249 highest obtained. Analyses using the current best practice approach, as defined by Fowmes et al.

250 (2007) are defined as “_Best_Practice” simulations. These analyses incorporate strain softening

251 interfaces between lining elements and use the measured, unaltered, material parameters.

252 Numerical modelling results using the basic approach produced limited agreement with the

253 measured behaviour, especially in terms of geotextile displacements (Figure 5 Geotextile MIN

254 plot). In general for the standard approach it was not possible to replicate geotextile movements

255 in the middle and top sections of the slope, with the largest movement in the model occurring

256 within the toe section. It can be noticed that the geotextile did not deform in a manner modelled.

257 Model output displacements are regular, with predictable trends that increase steadily until the

258 final stage of loading. However, on the site no significant movements occurred once the slope

259 was covered by the second sand veneer. Furthermore, results for the geotextile are in a good

260 agreement for the lower section of the slope where the geotextile was covered by the sand

261 veneer, and which was not left exposed for an extended period of time. Although behaviour

262 during staged construction is not well replicated, the final total displacements computed in the

263 range of 30mm for the lower section of the slope are consistent with the monitored values. For 
264 the top section of the slope, geotextile in situ displacements are comparable to the computed 265 ranges only when the values of interface shear strength of the lining components are reduced 266 significantly (e.g. MAX analysis shown in Figure 7). In the MAX analysis the geomembrane 267 movement is increased by assuming softening of the clay, thus reducing stiffness, and the 268 geotextile stiffness is increased to replicate the possible effects of weathering (Lodi et al. 2008).

269 The MAX analysis represents reasonably well the measured behaviour of the section of 270 geotextile that was exposed for an extended period (i.e. between placement of the first and 271 second sand veneers), however displacements within the lower sections are significantly 272 overestimated. The "Best_Practice” analysis is able to replicate behaviour of the geotextile for 273 the lower part of the slope length that was rapidly covered by the sand veneer.

274 Figure 6a-c present plots of selected analyses outputs versus site derived data, for each stage of 275 cell filling for three locations on the slope (i.e. extensometer locations: 8.4, 13.8 and $24.6 \mathrm{~m}$ 276 below the crest). The main movement for the upper section occurred directly before and during 277 placement of the second sand veneer. In the MAX analysis geotextile movements occur only 278 when the loading is placed directly over the geotextile (e.g. top extensometer at location $8.4 \mathrm{~m}$ 279 records increased movement when the $3^{\text {rd }}$ veneer is constructed (Figure 6a); middle extensometer 280 at $13.8 \mathrm{~m}$ when $2^{\text {nd }}$ veneer is placed (Figures $6 \mathrm{~b}$ ); and toe extensometer at $24.6 \mathrm{~m}$ due to $1^{\text {st }}$ 281 veneer placement (Figures 6c)). The highest displacements of the geotextile occurred in response 282 to placement of the $2^{\text {nd }}$ sand veneer. 
286 Measured geomembrane displacements gradually increased during filling at all locations, but

287 with only limited displacement caused directly by placement of the sand veneers. Maximum

288 displacement reached $25.9 \mathrm{~mm}$ within the middle section, but in general the extensometers

289 recorded displacements of 10-20 mm within the geomembrane panel. No significant correlation

290 was found between geotextile and geomembrane locations on the slope with increased

291 displacements.

292

293 Geomembrane displacements are represented by the numerical model with relatively good

294 agreement. While the MAX analysis overestimates geomembrane displacements, MIN and

295 "Best_Practice” (Figure 7) both represent the trend and magnitude of monitored values, although

296 values are underestimated in the lower section. For analyses using the "stiffer" clay properties

297 (150 MPa), not much difference in geomembrane movement was observed between the results

298 for the peak, residual, strain-softening and reduced interface shear strength approaches (Table 4).

299 4.2.3 Summary

300 Figure 7 presents measured and modelled displacement distributions for the geotextile and 301 geomembrane along the slope, after the final stage of construction. These plots highlight the 302 significant differences in computed geotextile and measured final displacement distributions.

303 The computed maximum geomembrane displacements for the basic analysis (MIN) are in the 304 range of the monitored values but the location of the maximum geomembrane movements differ. 305 Considering behaviour during staged construction (Figures 6a-c) it can be observed that the basic 306 analysis is sufficient to replicate the geomembrane behaviour, however for all instrumented 307 locations the geotextile deformations are underestimated by the basic analysis. 
309 Simulations using peak and residual interface shear strengths gave very similar results. For the

310 basic simulation (MIN), the maximum computed geomembrane displacement is within the range

311 of monitored geomembrane displacements (i.e. $20 \mathrm{~mm}$ ), although the location of its occurrence

312 is not well represented in the model This behaviour is consistent with the expectation that

313 mobilised strengths are below peak values for shallow slopes such as investigated in this study.

314 For the geotextile, difficulty was experienced trying to model the exposed section of the material

315 in the upper part of the slope, while the part that was covered by the sand veneer within a few

316 months of liner construction is relatively well modelled using the strain - softening approach

317 (Best_Practice). Due to the complex measured behaviour of the geosynthetics and variability of

318 the conditions they were exposed to, it is difficult to select a "best fit" analysis for the whole

319 slope, as none of the models can reproduce measured behaviour at all areas of the slope in each

320 construction stage. The "Best_Practice” model using measured and best estimate parameters,

321 produced the most consistent fit with observed deformation of the geomembrane and for the

322 lower section of geotextile that was rapidly covered by the sand veneer.

3234.3 Strains in the geomembrane imposed by the veneer and waste loading vs. model predictions

324 Strains in the geomembrane were measured using three independent methods: Demec strain

325 gauges with reading points installed at the top and middle slope sections, fibre optic sensors

326 located in the middle and bottom slope sections (all the sensors were lost prior to the 3rd veneer

327 placement) and extensometers covering the entire slope length. Demec gauges were used to

328 measure strains over a relatively short gauge length of $20 \mathrm{~cm}$. Three measurement positions

329 across the width of the geomembrane panel were located at the slope crest and one position on

330 the panel centreline in the middle of the slope. Extensometer readings can be used to calculate

331 strains but this information is low resolution as measuring points installed on the geomembrane 
are a $5.4 \mathrm{~m}$ apart, hence strains are average values over this gauge length and only provide low resolution information. The fibre optic sensors provide measurements of average strains over a $1 \mathrm{~m}$ long gauge length orientated parallel to the slope. Strain measurements are compared at three stages of construction: after placement of the 1st sand veneer, just prior to placement of the $2^{\text {nd }}$ sand veneer and the final stage after completion of waste filling. For comparison, average values for the measurement sections have been obtained from the model outputs. Monitored and modelled strains in the geomembrane are presented in Figures 8a-c for locations at the top, middle and bottom of the slope. The accuracy, resolution and hence reliability of strain measurements using the different approaches are discussed by Zamara et al. (2012). Despite some issues with reliability and reproducibility of measured values, it is considered that the magnitude of the strains is given and comparison of measurements obtained using the different techniques provides confidence in observed trends.

General trends of measured and modelled strains can be identified. The modelling gives compressive strains for the toe section throughout the cell filling stages, while tension in this section was measured on site. This is due to the fact that the toe of the geomembrane moved the most due the presence of a compressible shredded tyre basal drainage layer at the toe of the slope), while the model gives peak displacements at a position $25 \mathrm{~m}$ below the slope crest (i.e. 6 $\mathrm{m}$ above the toe). The middle section experienced a constant tension state and this is replicated in the model although it is underestimated in the basic analysis. Strains computed for the top section are in tension throughout the filling stages and this agrees with Demec strain gauge readings. The extensometer records give compressive strains in the top slope section throughout almost all the stages of construction. This is suspected to be related to temperature effects on the extensometer wires that were difficult to correct and hence there is lower confidence in these measurements. For the final stages only the extensometer readings are available and the accuracy 
356 of these is limited as outlined above. In general, the model gives the same strain trends but

357 different magnitudes.

\section{Strains recorded after placement of the 1st sand veneer}

359 When the toe of the slope was covered by the $0.5 \mathrm{~m}$ thick sand layer the model indicates

360 geomembrane compression at the toe and tension within the uncovered sections up slope (Figure

361 8a). However, in situ measurements shows that placement of the sand veneer caused tensile

362 strains greater than $0.1 \%$ within the loaded sections of the liner and generally smaller

363 (extensometer and fibre optic measurements) tensile strains of $0.06 \%$ within the sections above.

364 However, the Demec strain gauge measurements show higher tensile strains in the exposed

365 geomembrane of $0.15 \%$ and $0.18 \%$ for the crest and middle sections respectively.

366 Strains recorded just prior to placement of the 2nd sand veneer

367 Prior to the second veneer most of the instrumentation show tensile strains within the whole

368 length of the geomembrane (Figure 8b). In the toe section the fibre optic measurements reach

369 over $0.7 \%$ and for the extensometers over $0.2 \%$ while the top and middle sections stay in a range

370 of $0.1-0.2 \%$. The model MAX outputs give uniformly distributed tensile strains of $0.09 \%$ for the

371 exposed sections of the slope and indicates compression within the toe region.

$372 \quad$ Final stage strains following completion of waste filling

373 After placement of the $3^{\text {rd }}$ sand veneer the Demec gauge measurement locations were no longer

374 accessible and the fibre optic sensors were not operating, and therefore only extensometer

375 readings can be used to provide information on strains. These indicate tensile strains within the

376 middle and lower sections and compression within the top section of the slope. These only agree

377 with the computed values in the middle section of the slope.

378 Summary 
379 In terms of the ability of the model to represent in situ lining component performance, it can be 380 concluded that only general trends of behaviour can be reproduced. Monitored behaviour is more 381 complex and description of all the incorporated factors is beyond the basic analysis. The basic 382 model (MIN) represents the geomembrane behaviour in a very limited way, with underestimated 383 magnitudes of the recorded strains. The highest tensile strains are recorded at the very top point 384 of the slope directly adjacent to the anchor, while instrumentation records increased values 385 within the lower slope sections, with fibre optic measurements reaching $0.7 \%$ and extensometer 386 derived values around $0.2 \%$ throughout the monitoring period.

387 Additionally, the model is not able to represent compression/wrinkling/folding behaviour as this 388 is complicated numerically to describe and requires confined compressive parameters for the 389 geosynthetics that are not routinely available.

\section{LINER EXPOSED TO ATMOSPHERIC CONDITIONS}

392 It can be observed that the basic numerical analysis underestimates geotextile displacements,

393 hence it can be concluded that the major geotextile displacements occur due to factors which are 394 not represented in the FLAC modelling approach employed. Temperature/solar radiation 395 influences are not commonly considered in the standard design processes for landfill lining 396 systems. Additional analysis was undertaken in an attempt to investigate environmental (i.e.

397 temperature) influences on geosynthetic performance. Evidence was discovered on site 398 supporting the hypothesis that HDPE cyclic expansion and contraction caused wrinkle formation 399 in the geomembrane driving associated geotextile deformations. However while the 400 geomembrane contracts in response to reductions in temperature the overlying geotextile 401 material does not recover and this results in formation of permanent wrinkles in the exposed 402 geotextile following series of temperature cycles. The Milegate extensometer measurements 
403 revealed evidence of geomembrane/geotextile interaction and geotextile movement due to HDPE 404 geomembrane thermal deformation occurring within exposed areas of the side slope. The FLAC 405 analyses cannot replicate this mechanism of behaviour.

\subsection{Geosynthetics thermal behaviour - overview}

408 It is widely accepted that black geomembrane will absorb heat from the sun. HDPE exposed to 409 atmospheric conditions (i.e. solar radiation and high temperature amplitudes) will respond by 410 expanding or contracting, and this will occur in response to daily cycles and seasonal changes in 411 temperature and will result in cyclic wrinkle formation within the geomembrane. Studies of

412 geosynthetic thermal behaviour have been carried out by Giroud and Morel (1992) who

413 introduced a simplified model to describe wrinkle geometry and distribution on a horizontal 414 geomembrane due to thermal expansion/contraction behaviour. However, their procedure has 415 many limitations: the analysis was conducted for a horizontal surface while geomembranes are 416 widely installed on slopes with varying inclinations, the geometry of wrinkles in the

417 geomembrane was simplified and predictions regarding wrinkle occurrence and overall

418 behaviour were not fully considered. Studies regarding thermal behaviour of various

419 geomembranes (i.e. Koerner et al. 1993, Peltie et al. 1994, Cadwallader et al. 1993, Ehrenberg

420 \& Recker 2012) show the significant influence of geomembrane colour on the magnitude of

421 temperature reached during exposure and hence behaviour (i.e. up to $30^{\circ} \mathrm{C}$ difference between

422 white and black geomembrane). It has been recognised that HDPE surface temperature exceeds, 423 often significantly, monitored air temperature, and depends on the solar radiation (Peltie et al. 424 1994). Moreover, Take et al. (2011) have observed that wrinkles have increased temperatures 425 compared to the rest of the HDPE (due to air trapped underneath the wrinkle). Take et al. (2012) 426 reported temperatures up to $15^{\circ} \mathrm{C}$ higher than the unwrinkled HDPE. Additionally, Akpinar \& 
427 Benson (2005) report temperature effects on shear strength properties of

428 geomembrane/geotextile interfaces with increased friction angle with elevated temperature and

429 decreased values due to temperature decreases (reported change in interface strength friction

430 parameter was $2-3^{\circ}$ for $\Delta \mathrm{T}=33^{\circ} \mathrm{C}$ ). Existing research has focused on wrinkle behaviour when

431 subjected to overburden stresses, as these affect leakage flow.

432 In this study, the influence of geomembrane wrinkle formation on the overlaying geotextile

433 material is considered important for deformation of the lining system components during

434 construction and waste placement.

435 While there are extensive studies of HDPE wrinkling, to the authors' knowledge, data available 436 on geotextile wrinkle development in composite geosynthetic lining systems exposed to solar 437 radiation are limited. Lodi et al. (2008) investigated geotextile properties exposed to weathering. 438 It was reported that after three months, there was a reduction material tensile strength and mass 439 per unit area, but an increase in tensile stiffness. Information regarding geotextile wrinkle 440 formation, locations, sizes and displacements along the slopes are not well documented.

441 For this study temperature records for the upper surface of the geomembrane beneath the 442 geotextile (measured at the middle section of the slope) are presented in the Figure 9 for a period 443 of one year while the geosynthetics were exposed at this location. Daily changes in the 444 temperature reach up to $\Delta \mathrm{T}_{\mathrm{d}}=10^{\circ} \mathrm{C}$, while seasonal changes are of over $\Delta \mathrm{T}_{\mathrm{s}}=30^{\circ} \mathrm{C}$. Air 445 temperature recorded for this area in the same period, revealed seasonal temperature difference 446 of $40^{\circ} \mathrm{C}$ (WunderGround, 2012). The observed wrinkle formation, HDPE contraction and 447 expansion, and its influence on geotextile deformation is considered to be an important 448 behaviour explaining mechanisms of recorded increased displacements of the geotextile. 


\subsection{Discussion on thermal factors}

Based on observations and measurements at Milegate it is concluded that prolonged exposure to solar radiation has a significant influence on geosynthetic lining system performance. The upper section of the slope remained uncovered, and hence exposed, from installation in July 2009 until October 2011). Geomembrane deformations due to seasonal temperature changes are shown by the Demec strain gauge measurements made at the top and across the slope (Figure 10), and these deformations are also detected by the extensometer deformation measurements. Cyclic daily deformations were not directly monitored; however changes in geomembrane and geotextile wrinkling over a period of hours were observed during site visits. Wrinkles were documented in site photographs (e.g. Figure 11). It is considered that geomembrane seasonal thermal expansion was reproduced by the overlying geotextile. The geomembrane was installed during the summer time (i.e. during a period of high temperatures), hence expansion would be at or close to maximum. Because the geomembrane is anchored, as is the geotextile, at the top of the slope, temperature decrease towards the first winter season would result in material contraction, which is represented by readings from extensometers Ext1 and Ext2, which demonstrate small movements up slope. Non-woven geotextile contracts only a small amount when temperatures drop and hence although wrinkles in the geomembrane disappeared in periods of low temperature, those in the geotextile did not. Figure 11 shows a geotextile wrinkle,

467 which is not supported underneath by a geomembrane wrinkle. Although geomembrane wrinkle 468 formation is replicated by the geotextile, the shrinking of wrinkles is not.

469 In a simplified evaluation of the geosynthetic thermal in situ behaviour, HDPE thermal 470 expansion was calculated for two coefficients: $1.1 \times 10^{-4} \mathrm{~cm} / \mathrm{cm} /{ }^{\circ} \mathrm{C}$ (Koerner 2005) and $1.5 \times 10^{-}$

$471{ }^{4} \mathrm{~cm} / \mathrm{cm} /{ }^{\circ} \mathrm{C}$ (Sheirs 2009) in conjunction with ranges of temperature seasonal changes recorded 
472 directly on the site $\left(\Delta \mathrm{T}_{\mathrm{s}}=30^{\circ} \mathrm{C}\right.$, Figure 9$)$, and in the region $\left(\Delta \mathrm{T}_{\mathrm{s}}=40^{\circ} \mathrm{C}\right.$, WunderGround,

473 2012). The results of this simplified analysis are presented in Table 5 where they are compared

474 with the down slope deformations of the geotextile measured during placement of the $2^{\text {nd }}$ sand

475 veneer. It can be seen that these are comparable. It is concluded that existence of wrinkles in the

476 exposed section of geotextile allowed rapid downslope displacements to occur during loading

477 from the sand. This resulted in relative shear displacements between the geomembrane and

478 geotextile and has implications for mobilisation of interface shear strength and hence for stability

479 of the side slope lining system.

480

4816 PROJECT LIMITATIONS/COMMENTS

482 Considerable effort was expended to ensure selection of appropriate instruments and correct

483 installation that would provide reliable and consistent measurements. Nevertheless it is

484 acknowledged that the study has several limitations:

$485 \quad$ - $\quad$ All the instruments were subjected to temperature changes and hence thermal corrections

486 are required. These were based on the coefficients available from the literature (details

487 are presented in Zamara et al. 2012), but it is noted that thermal calibration of the

488 materials and instruments is a challenging task;

$489 \quad$ - Extensometer readings represent localised movement of the six attachment points on the

490 geomembrane and geotextile and these may not adequately reflect the behaviour of the

$491 \quad$ entire material sheets (i.e. wrinkle formation);

$492 \quad$ - Strains calculated from extensometer records are averaged over 5.4m gauge lengths and

493 therefore average local behaviour; 
- Geomembrane strain information acquired from the fibre optic sensors are more comprehensive as the sensors were installed at $1 \mathrm{~m}$ gauge lengths along the geomembrane, however sensors were lost due to damage throughout the project and therefore no readings are available after placement of the $3^{\text {rd }}$ sand veneer;

- Most of the instrumentation was installed along the centre line of the panel and plane strain conditions are assumed, however the field trial was only one panel wide, thus lateral strain may have occurred; and

- Additionally, it is recognised that validation of numerical modelling design approaches currently in use would benefit if more of this type of monitoring data was available, particularly for different lining system configurations, slope geometries and with consideration given to various rates of waste placement, not only in terms of geosynthetics loadings but also lengths of time the lining exposure to atmospheric conditions.

\section{CONCLUSIONS}

The Milegate Extension Landfill monitoring project was conducted for three years. The initial aim was to validate standard design approaches incorporating numerical modelling and to better understand mechanisms affecting lining system in-service performance.

The Milegate study provides information on the lining system performance before and during waste placement, which is presented here, and it is planned to conduct further monitoring after landfill closure as waste degradation and settlement occurs. Collected data included: stresses imposed on the lining system, geosynthetic displacements, geosynthetic strains and temperature and these are presented in the paper. Numerical modelling of the monitored slope was conducted 
517 using a range of material models and ranges of key parameters. Selected analyses using FLAC

518 are presented in this paper and compared with the site measurements.

519 Monitoring revealed that exposed sections of geotextile experienced significant displacements.

520 This behaviour of the lining system could not be replicated using a numerical model. However,

521 current best practice modelling is able to reproduce observed behaviour of the lining components

522 when they are covered and hence not subject to cycles of temperature driven by solar radiation. It

523 is concluded that the observed geotextile displacements that occurred during placement of the $2^{\text {nd }}$

524 sand veneer are a result of the presence of irrecoverable wrinkles in exposed areas of the slope

525 driven by thermal expansion of the underlying geomembrane. It is acknowledged that the

526 influence on composite liner behaviour of prolonged exposure to weather conditions is currently

527 poorly understood. In an attempt to replicate this behaviour, analyses were conducted using

528 reduced values of the lining system interface shear strength and modified soil and geotextile

529 material properties (i.e. reduced interface shear strength of the lining components reflecting

530 wrinkling of the exposed materials and ageing of the geosynthetics) but this approach was not

531 able to reproduce measured displacements .

532 It should be emphasised that for the section of slope covered by the sand veneer, where the 533 geosynthetics are not directly exposed to solar radiation, displacement values computed using a

534 standard modelling approach are comparable to measured values. This indicates that standard

535 numerical modelling approaches are not applicable when prolonged expose of the geosynthetics

536 and thermal effects become the dominant mechanism controlling displacements.

537 It is uncommon to consider temperature effects on performance of geosynthetic based landfill

538 side slope liner systems as this is significantly more complicated than the standard design

539 approach. However, attempts should be made to assess the likely influence of cycles of 
temperature on performance if it is expected that the liner will be left uncovered for a prolonged

541 period of time due to slow filling rates. Relative displacement between the geotextile and

542 geomembrane can result in mobilisation of post peak interface shear strengths and hence reduced 543 stability that could lead to uncontrolled slippage of the liner and overlying waste. It is advised

544 that if geosynthetics might be exposed to weathering for a prolonged time, reduced values for

545 interface shear strength, and modified values for materials properties, should be considered in 546 design.

\section{ACKNOLEDGEMENTS}

548 EPSRC, CICE at Loughborough University and Golder Associates UK Ltd funded Engineering

549 Doctorate student Katarzyna Zamara. The Authors wish to thank Milegate Extension Landfill

550 Management for their support, which made the project possible. Special thanks are due to Scott

551 Hodges from Sandsfield Gravel Ltd for technical support. The authors also wish to thank

552 GeoFabrics Ltd and VEOLIA Environmental Services Ltd for providing geomembrane and

553 geotextile materials respectively and to the Environment Agency England and Wales for their

554 support of the trial. Finally thanks are due to Dr Steve James and his researchers at Cranfield

555 University for developing and installing the fibre optic strain measurement system.

\section{REFERENCES}

557 Akpinar, M.,V., Benson, C.H., 2005. Effect of temperature on shear strength of two 558 geomembrane-geotextile interfaces. Geotextiles and Geomembranes, v 23, issue 5, October 559 2005, pages 443-453.

560 Arab, M., 2011, The Integrity of Geosynthetic Elements of Waste Containment Barrier Systems 561 Subject to Seismic Loading. PhD thesis, Arizona State University. July 2011.

562 Cadwallader, M., Cranston, M., Peggs, I.D., 1993. White surfaced HDPE geomembranes:

563 assessing their significance to liner design and installation. Proceedings of geosynthetics '93, 564 vol. 2, pp. 1065-1079. 
565 Dixon, N., Jones, D. R., 2003. Stability of Landfill Lining Systems: Report no.2 Guidance.

566 Environment Agency Research and Development Technical Report P1-385/TR2.

567 Dixon, N., Jones, D. R., 2005. Engineering properties of municipal solid waste. Geotextiles and 568 Geomembranes 23, pp. 205-233.

569 Dixon, N., Jones, D.R.V. , Fowmes, G.J., 2006. Interface shear strength variability and its use in 570 reliability-based landfill stability analysis. Geosynthetics International. Vol. 13, No1. p 1.

571 Dixon, N., Zamara, K.A., Jones, D.R.V., Fowmes, G., 2012. Waste/Lining System Interaction:

572 Implications for Landfill Design and Long-term Performance. Geotechnical Engineering Journal 573 of the SEAGS \& AGSSEA Vol. 43 No.3 September 2012 ISSN 0046-5828.

574 Ehrenber, H., Recker, C., 2012. The influence of Geosynthetics Color on the UV resistance 575 performance under natural and lab testing conditions. $5^{\text {th }}$ European Geosynthetics Congress. 576 Valencia 2012. Proceedings Vol. 5. Topic: Mining \& Environmental Applications.

577 Filz, G.M., Esterhuizen, J.J.B., Duncan, J.M., 2001. Progressive failure of lined waste 578 impoundments. Journal of Geotechnical and Geoenvironmental Engineering. October 2001, pp. 579 841-848.

580 Fowmes, G.J., Jones, D.R.V., Dixon, N. 2005. Analysis of a landfill directive compliant steep 581 wall lining system. Proceedings $10^{\text {th }}$ International Waste Management and Landfill Symposium, 582 Sardinia. pp369.

583 Fowmes, G.J., Dixon, N., Jones, D.R.V., 2007. Landfill Stability and Integrity Toolbox. Internal 584 Golder Associates (UK) Ltd Design Guidance Document.

585 Fowmes, G.J., Dixon, N., Jones, D.R.V., 2008. Validation of a numerical modelling technique 586 for multilayered geosynthetic landfill lining systems. Geotextiles and Geomembranes 26, pp. 587 109-121.

588 Giroud, J.P., Morel, N., 1992. Analysis of geomembrane wrinkles. Geotextiles and

589 Geomembranes, 11, 1992, pp. 255-276

590 Gudina, S. and Brachman, R.W.I., 2011. Geomembrane strains from wrinkle deformation.

591 Jones, D.R.V., Dixon, N., 2005. Landfill lining stability and integrity: the role of waste

592 settlement. Geotextiles and Geomembranes 23, pp. 27-53.

593 Koerner, R. M., 2005. Designing with Geosynthetics, 5th Edition. Prentice Hall, Englewood Cliffs, NJ, 594 USA, 816 pp.

595 
596 Koerner, R.M., Hsuan, Y., Lord, A.E., Jr., 1993. Remaining technical barriers to obtaining

597 general acceptance of geosynthetics, Geomembranes and Geotextiles, vol. 21, no. 1, pp. 1-53.

598 Koerner, R.M., Soong, T-Y. 2000. Stability Assessment of 10 Large Landfill Failures Geodenver 5992000 ASCE SPECIA vol 103, pp. 1-38.

600 Lodi, P.C, de Souza Bueno, B., Zornberg, J.G., de Souza Correia, 2008. Analysis of mechanical 601 properties on geotextiles after weathering exposure. Conference proceedings EuroGeo4 paper no 602203.

603 Muhsiung, C., 2005. Three-dimensional stability analysis of the Kettleman Hills landfill slope 604 failure based on observed sliding-block mechanism. Computers and Geotechnics 32, pp. 587605599.

606 Peltie, T., Pierson, P., Gourc, J.P., 1994. Thermal analysis of geomembrane exposed to solar 607 radiation. Geosynthtetic international, vol. 1, no. 1, pp. 21-44.

608 Sia, A, Dixon, N., 2012. Numerical modelling of landfill lining system-waste interaction: 609 implications of parameter variability. Geosynthetics International, Volume 19, Issue 5, 01 610 October 2012 , pages 393 -408, ISSN: 1072-6349, E-ISSN: $1751-7613$

611 Sheirs, J., 2009. A guide to Polymeric Geomembranes: A practical approach. John Wiley \& 612 Sons. ISBN 978-0-470-51920-2

613 Take, W.A., Watson, E., Brachman, R.W.I., Rowe, R.K., 2012. Thermal expansion and 614 contraction of geomembrane liners subjected to solar exposure and backfilling. Journal of 615 Geotechnical and Geoenvironmental Engineering.

616 Villard, P., Gourc, J.P., Feki, N., 1999. Analysis of geosynthetic lining system (GLS) undergoing 617 large deformations. Geotextiles and Geomembranes, Volume 17, Issue 1 February 1999, pp. 1761832.

619 WunderGround, 2012. Web site accessed on 01/06/2012:

620 http://www.wunderground.com/weatherstation/WXDailyHistory.asp?ID=IEASTYOR11\&day=6

621 \&year=2010\&month=5\&graphspan=year

622 Zamara, K.A., Dixon, N., Jones, D.R.V., Fowmes, G., 2012. Monitoring of a landfill side slope 623 lining system: Instrument selection, installation and performance. Geotextiles and

624 Geomembranes, 35 (2012) pp.1-13. 
625 Figure 1. Milegate Extension Landfill - the slope view 2010 and 2012, location of the slope and 626 basic geometry (after Zamara et al. 2012).

627

628
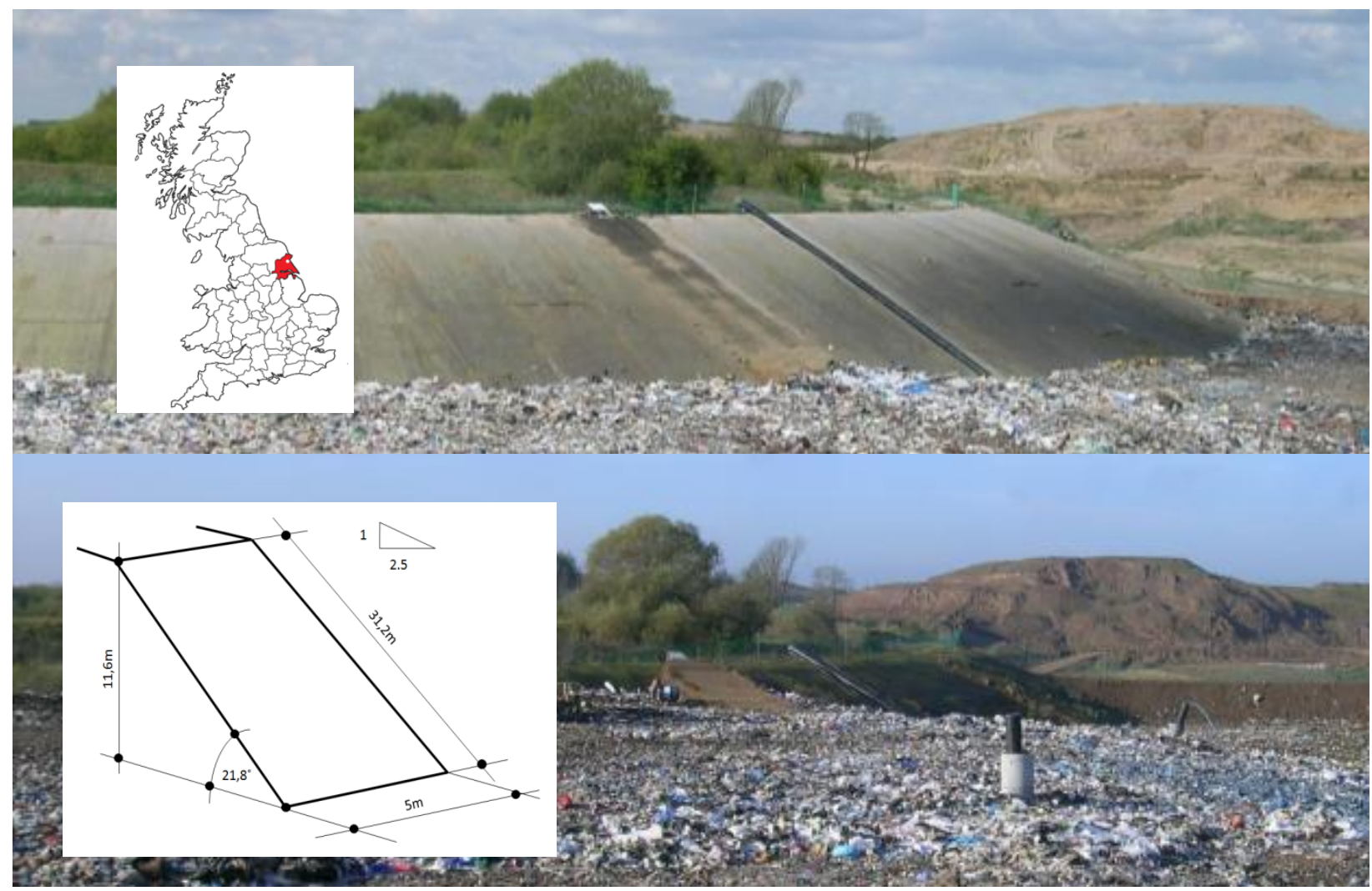
Figure 2. Multilayered side slope lining system - schematic view.

631

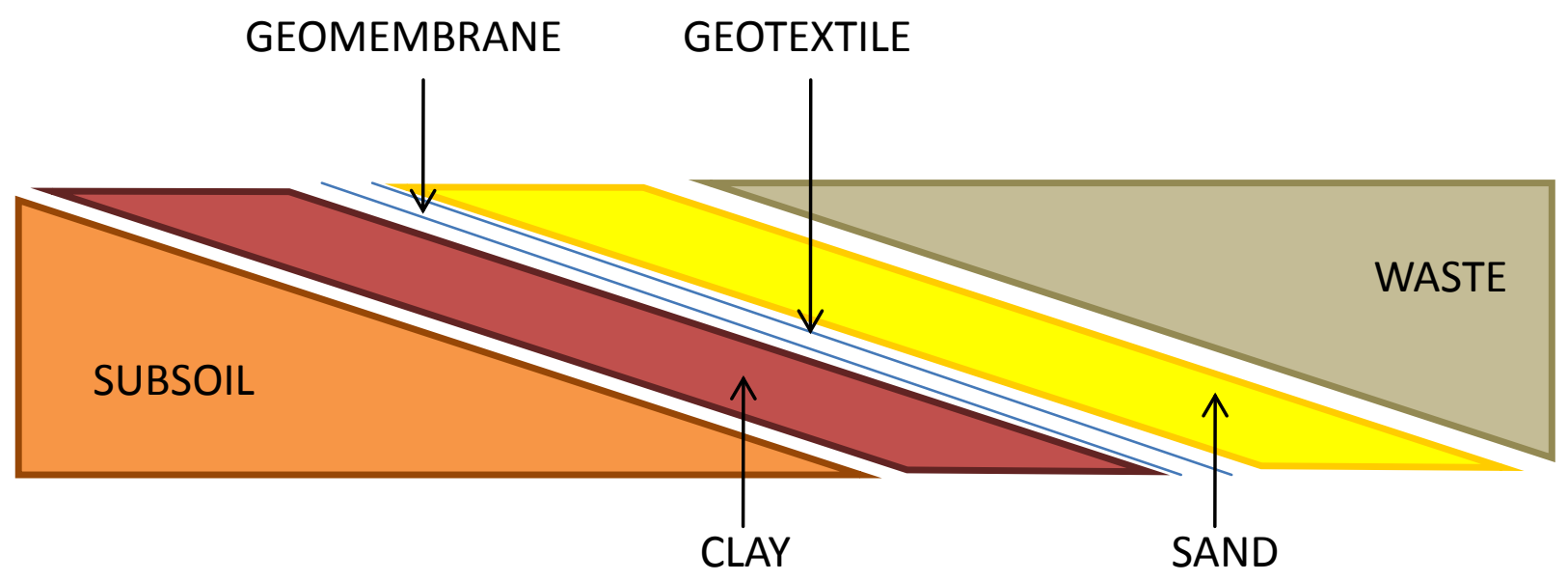


Figure 3. Instrument locations on the slope test panel - schematic view (after Zamara et al. 633 2012).

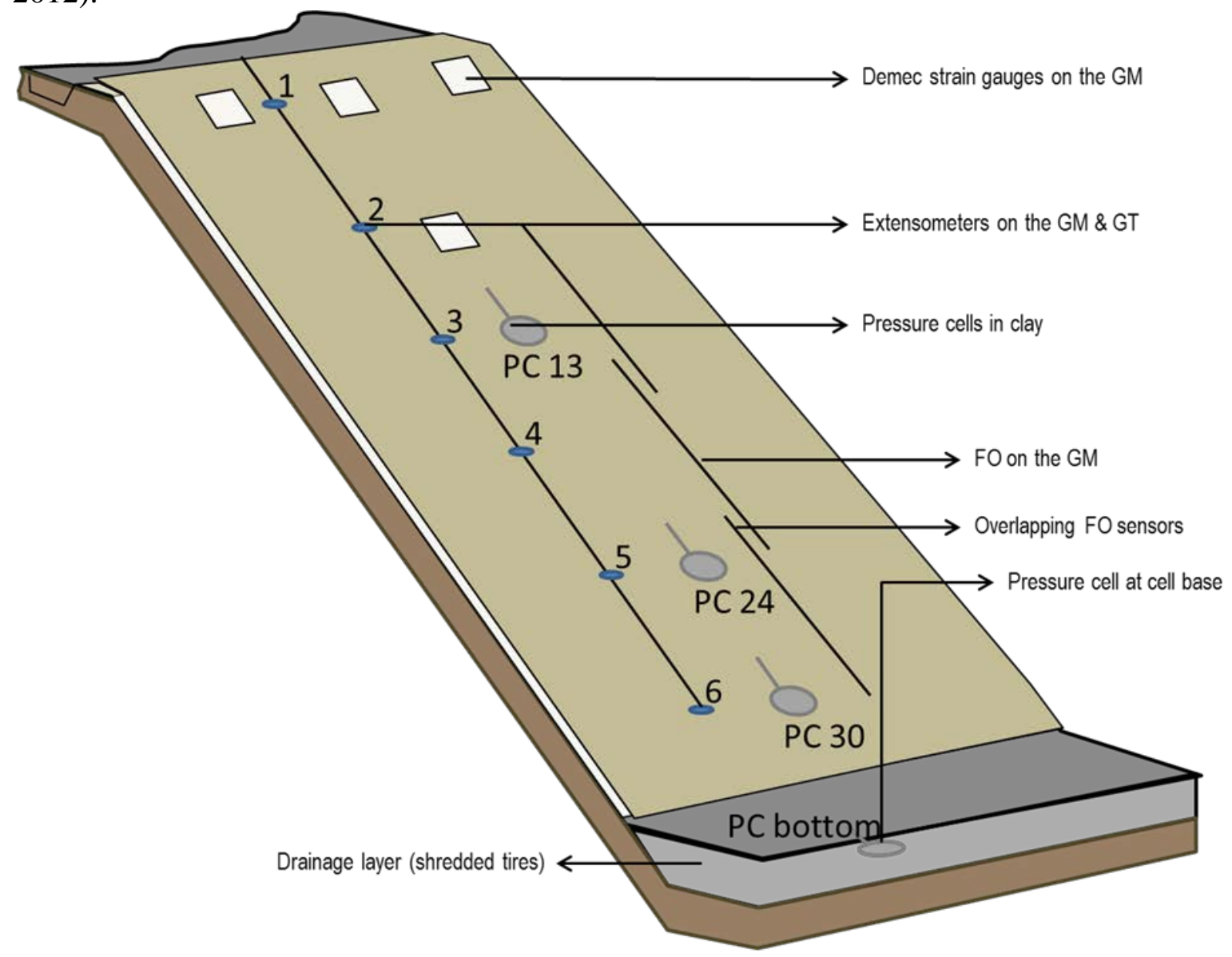

634 
635 Figure 4. Measured pressures on the liner from sand veneers and waste (pressure cells) and 636 computed values. All the values measured and computed are plotted correspondingly to the on637 site instrument locations (left hand Y-axis represents slope length from the crest to the toe (0$63831.2 \mathrm{~m}), \mathrm{X}$ - time axes are located in the relevant site instrument locations along the slope, right 639 hand Y axis - represents waste height above toe of slope with the corresponding plot of the slope 640 waste coverage). 
Measured \& Calculated Normal Stresses [KPa] $\&$ Measured Clay Surface Temperature $\left[{ }^{\circ} \mathrm{C}\right]$

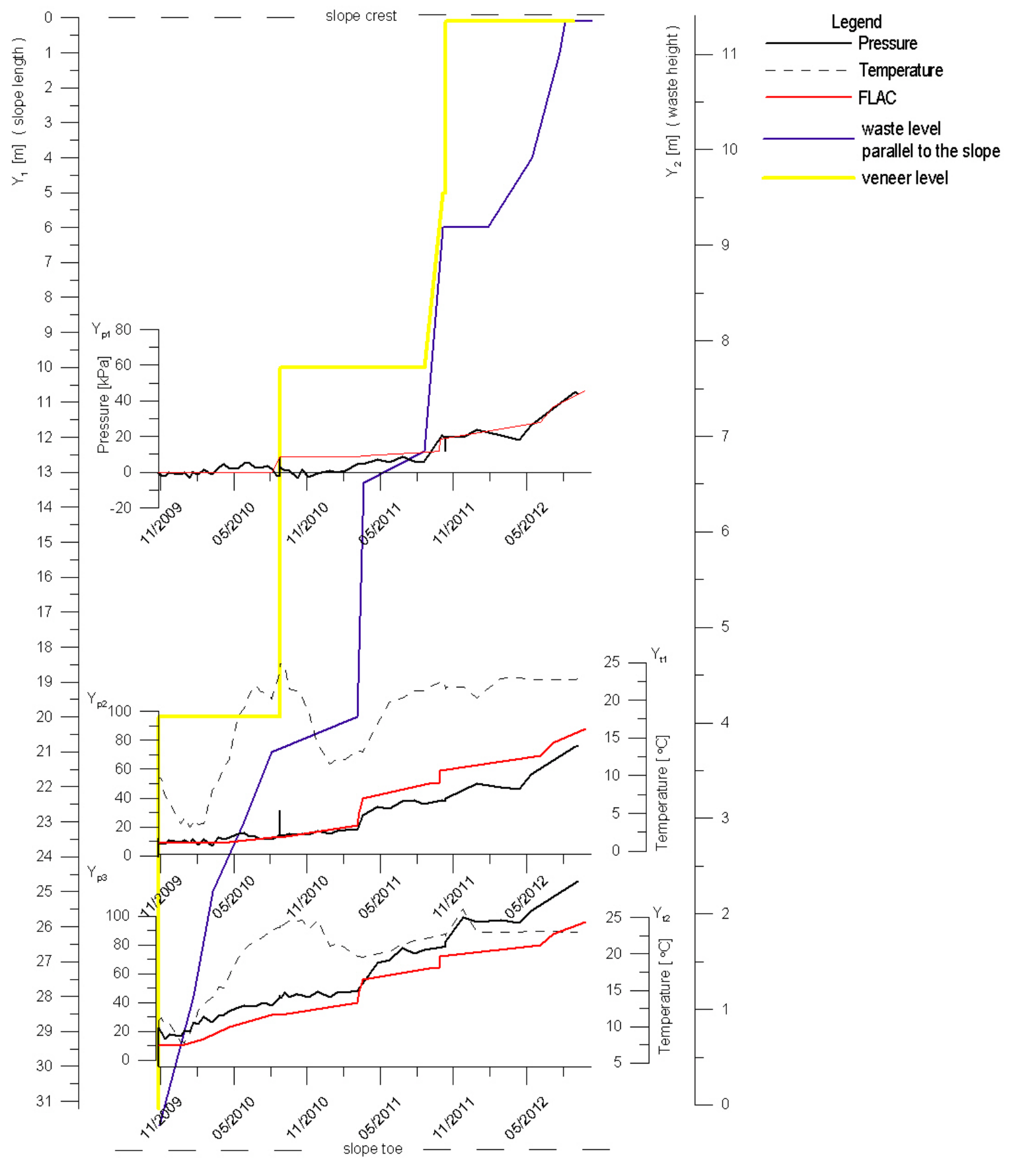


642 Figure 5. Extensometer readings with plots presented in the same manner as Figure 4.

643 Extensometer locations on the slope are reflected on the left hand side axis, which represents

644 slope length starting from the crest measured parallel to the slope (i.e. each $\mathrm{X}$ axis is positioned

645 at the measuring point along the slope). Displacements of each pair of extensometers

646 (geomembrane and geotextile) are plotted on a relevant X-axis, with the same direction of the

647 movement (up or down the slope) as occurred on the slope. Results from FLAC numerivcal

648 analyses are also shown for comparison.

649

650 


\section{Geomembrane \& Geotextile Extensometers Measured \& Computed Displacements [mm]}

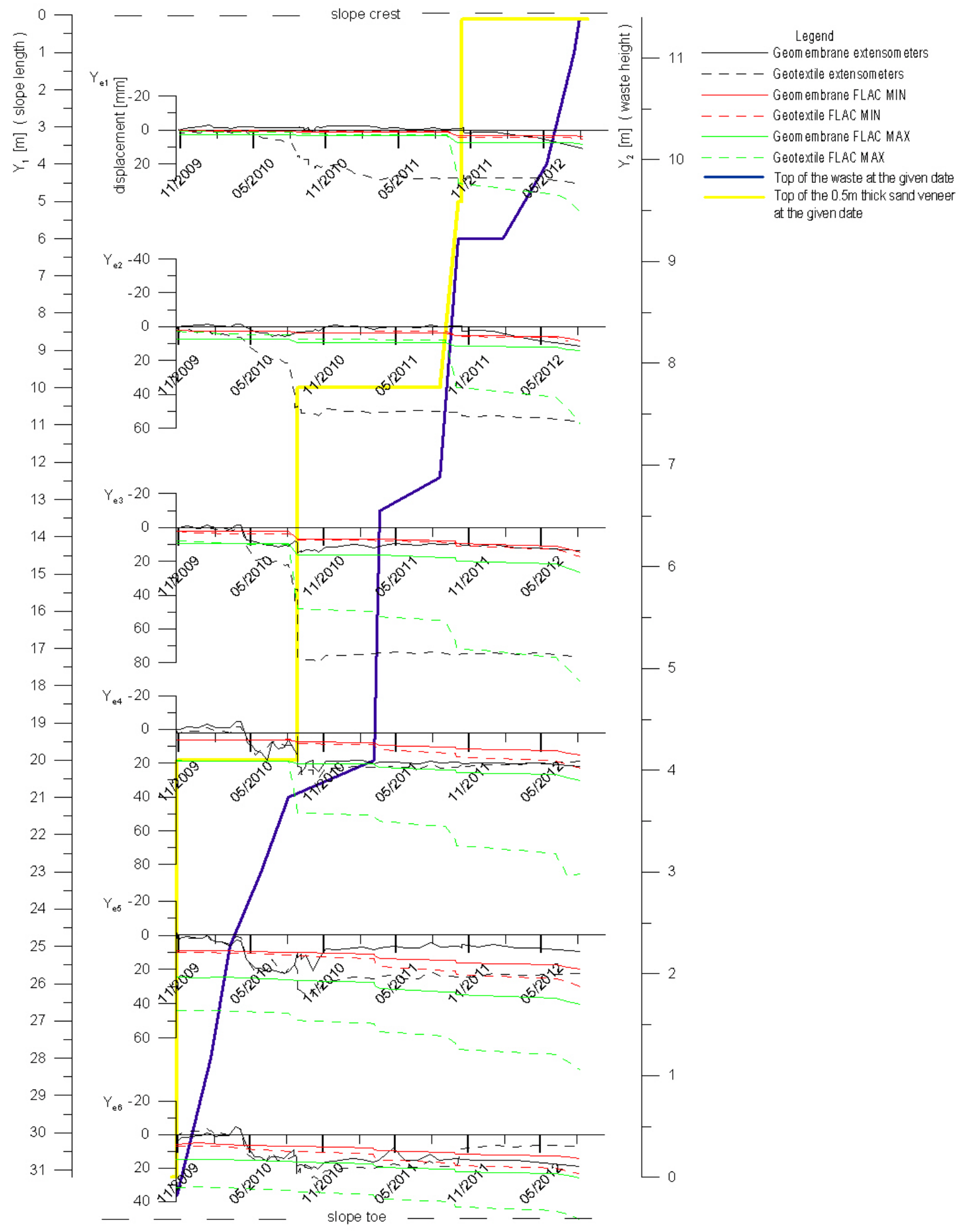

651 
653

654

655

656

657
Figure 6. Extensometer displacement measurements compared to displacements from selected numerical model analyses for the geomembrane and geotextile during staged construction at the following locations: a) $8.4 \mathrm{~m}$ below the crest, b) $13.8 \mathrm{~m}$ below the crest, c) $24.6 \mathrm{~m}$ below the crest.

a)

\section{$8.4 \mathrm{~m}$ below the crest}

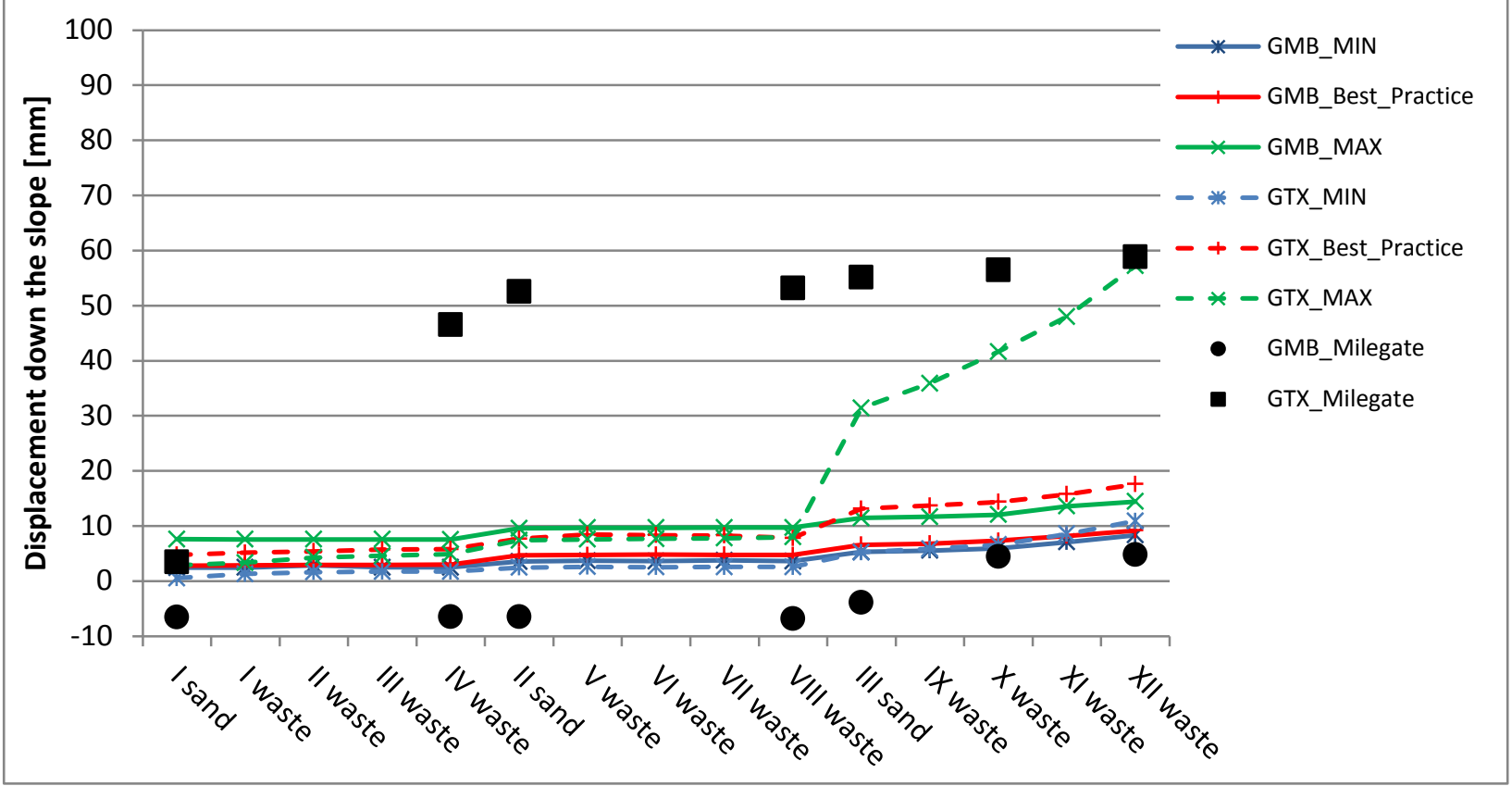


b)

$13.8 \mathrm{~m}$ below the crest

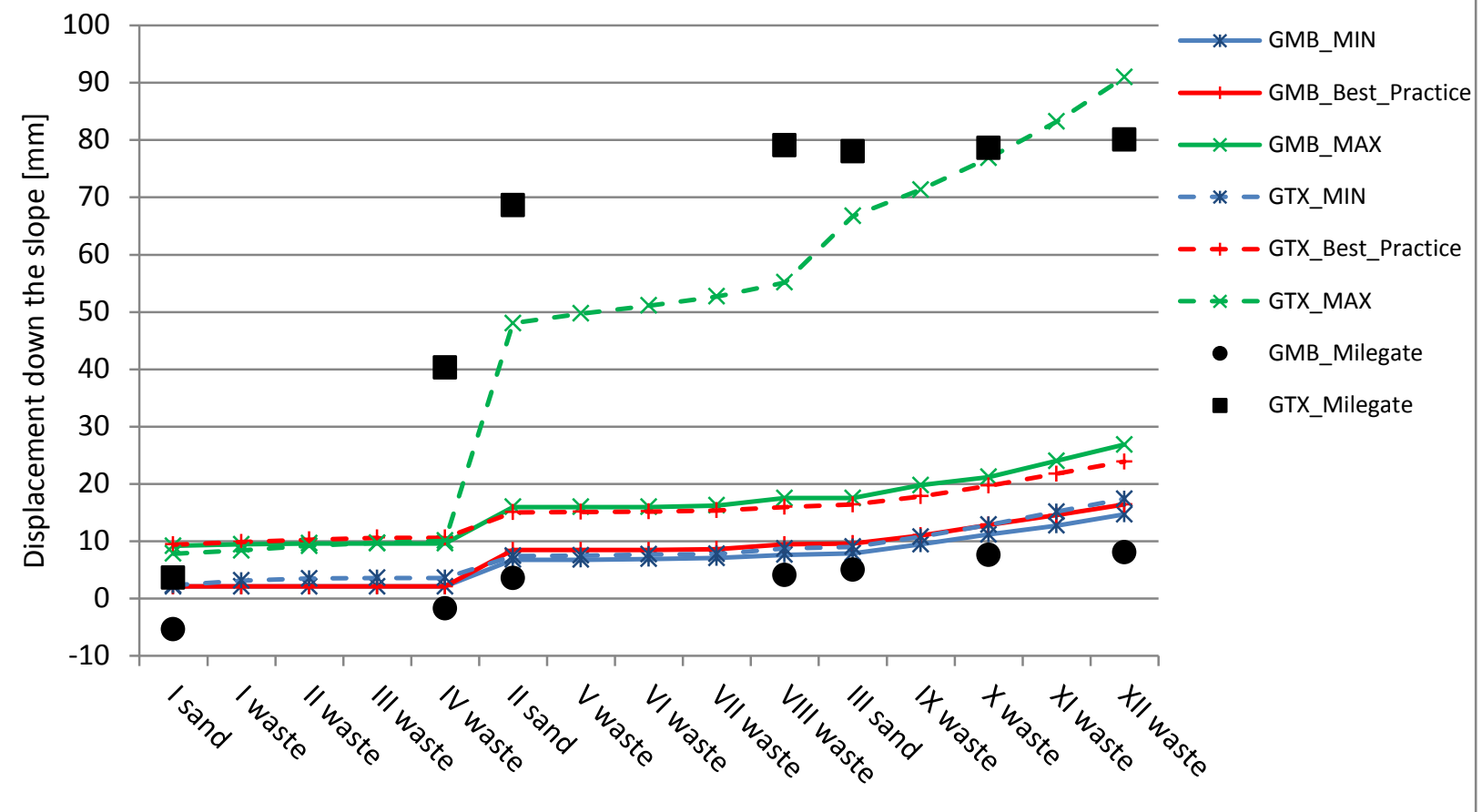

659

c)

$24.6 \mathrm{~m}$ below the crest

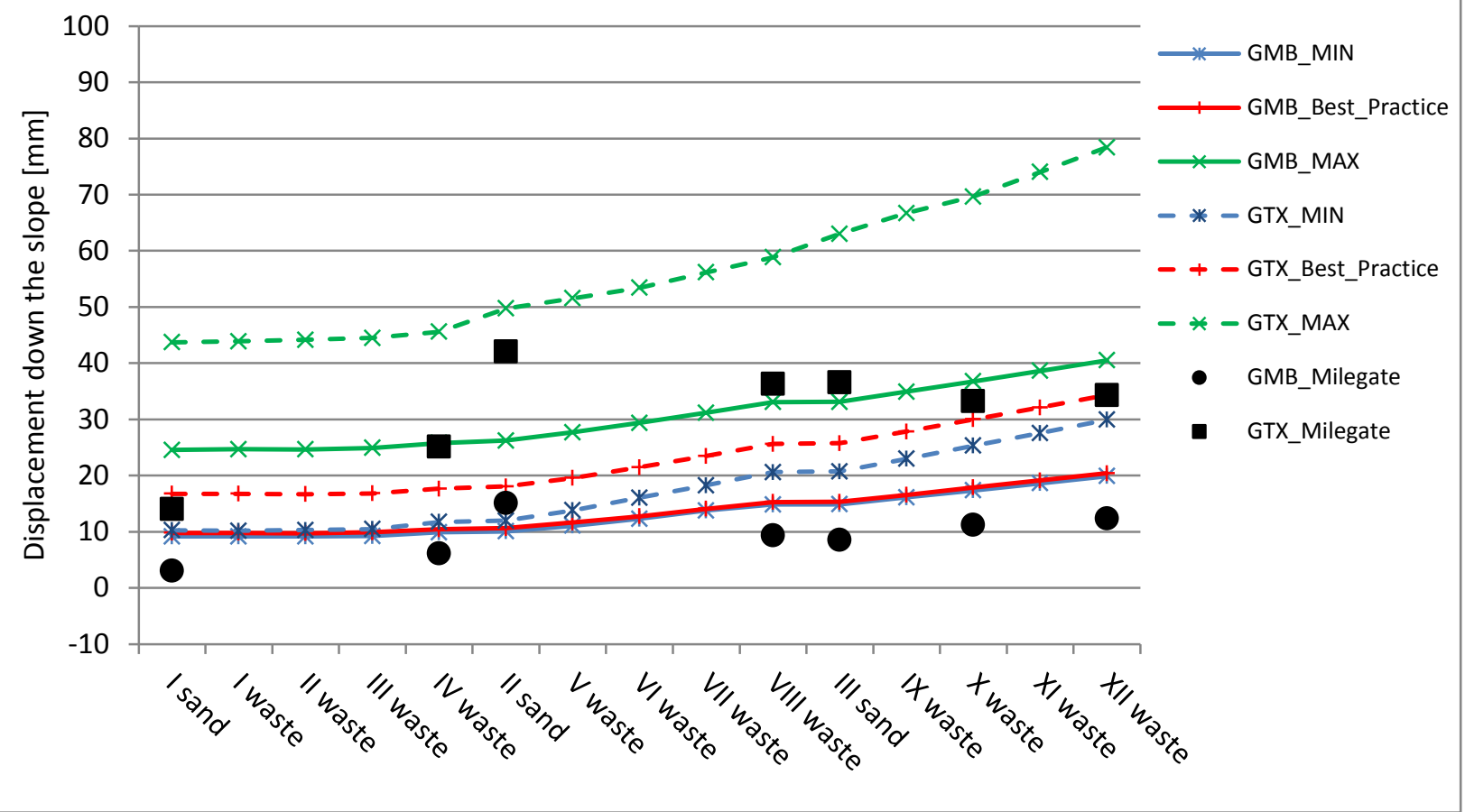


661

662

Figure 7. Comparison of measured and computed displacements following completion of waste filling

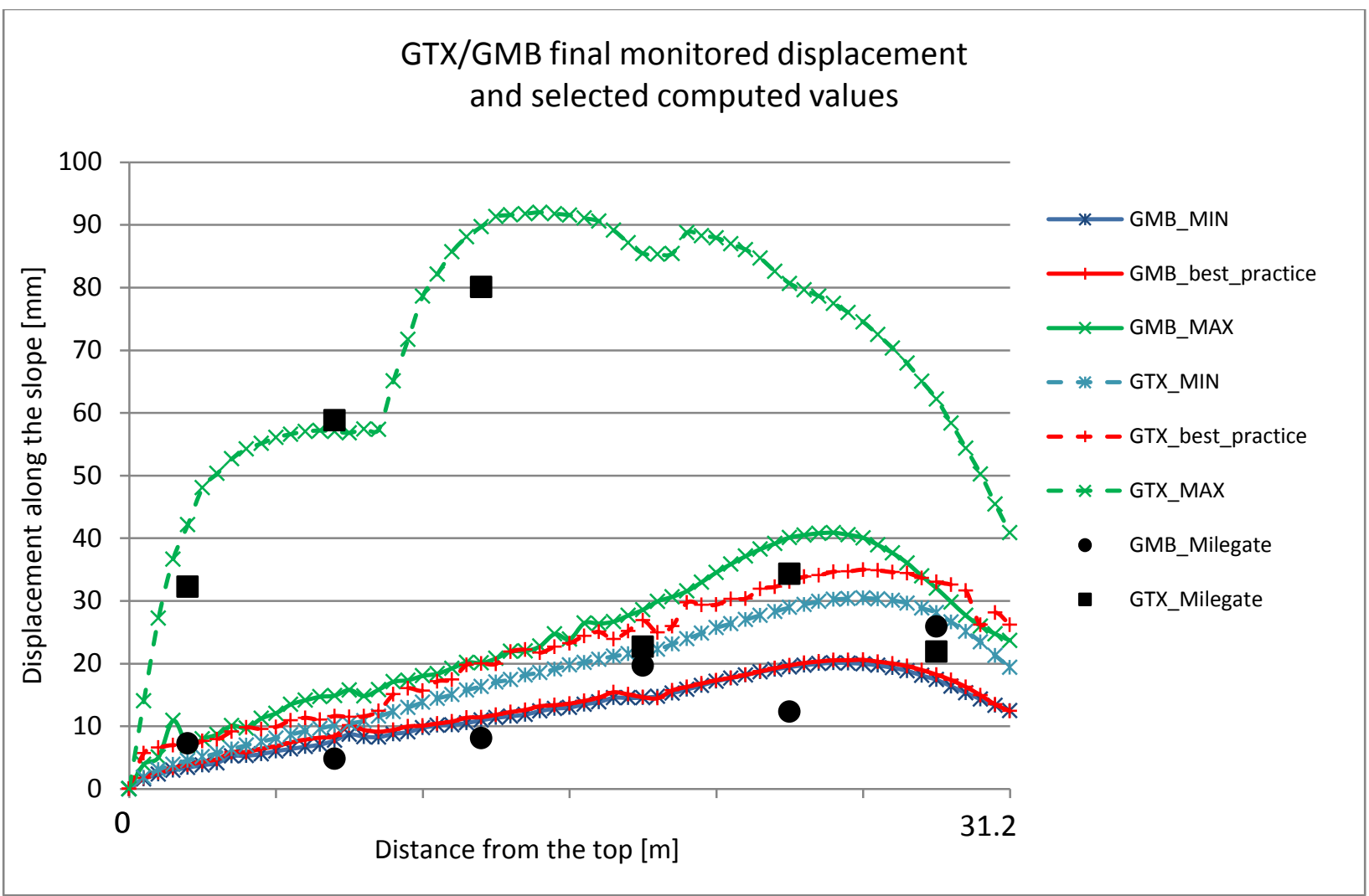

664

665

666 
Figure 8. Comparison of measured and computed geomembrane strains: a) after placement of the

668 1st veneer, b) prior to placement of the $2^{\text {nd }}$ veneer, and c) following completion of waste filling.

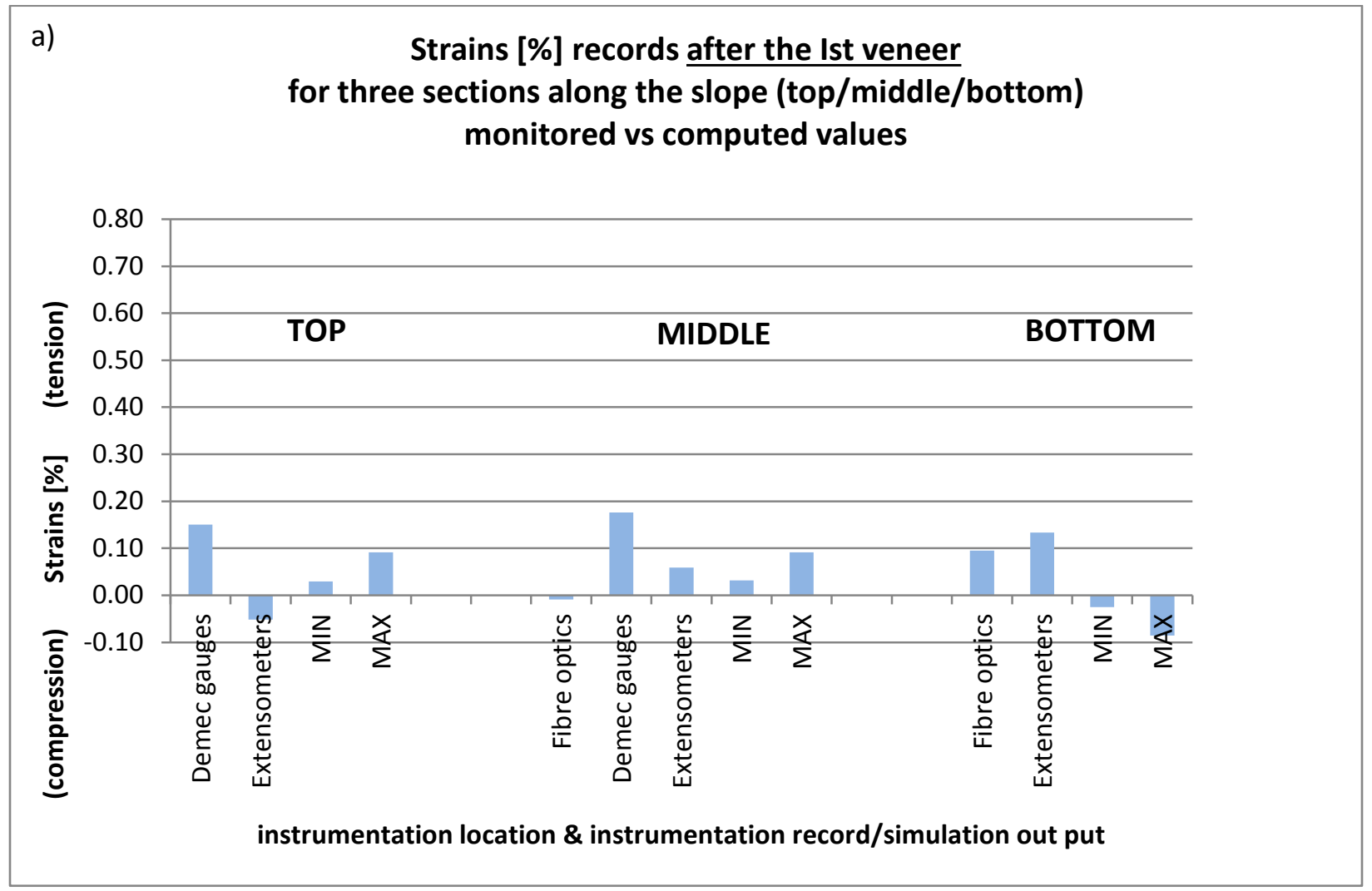

670

671 
b)

Strains [\%] records prior to the II veneer for three sections along the slope (top/middle/bottom) monitored vs computed values

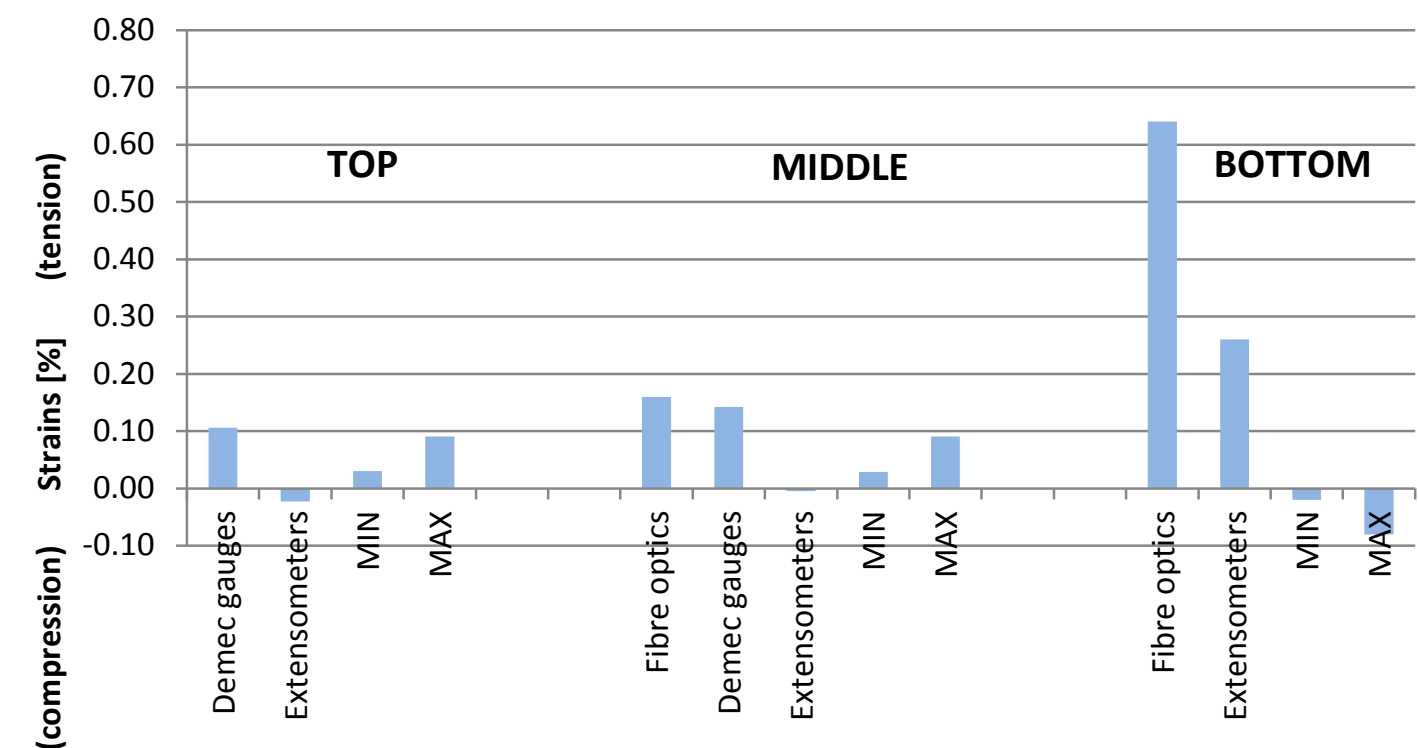

instrumentation location \& instrumentation record/simulation out put

c)

Strains [\%] records FINAL STAGE

for three sections along the slope (top/middle/bottom)

monitored vs computed values

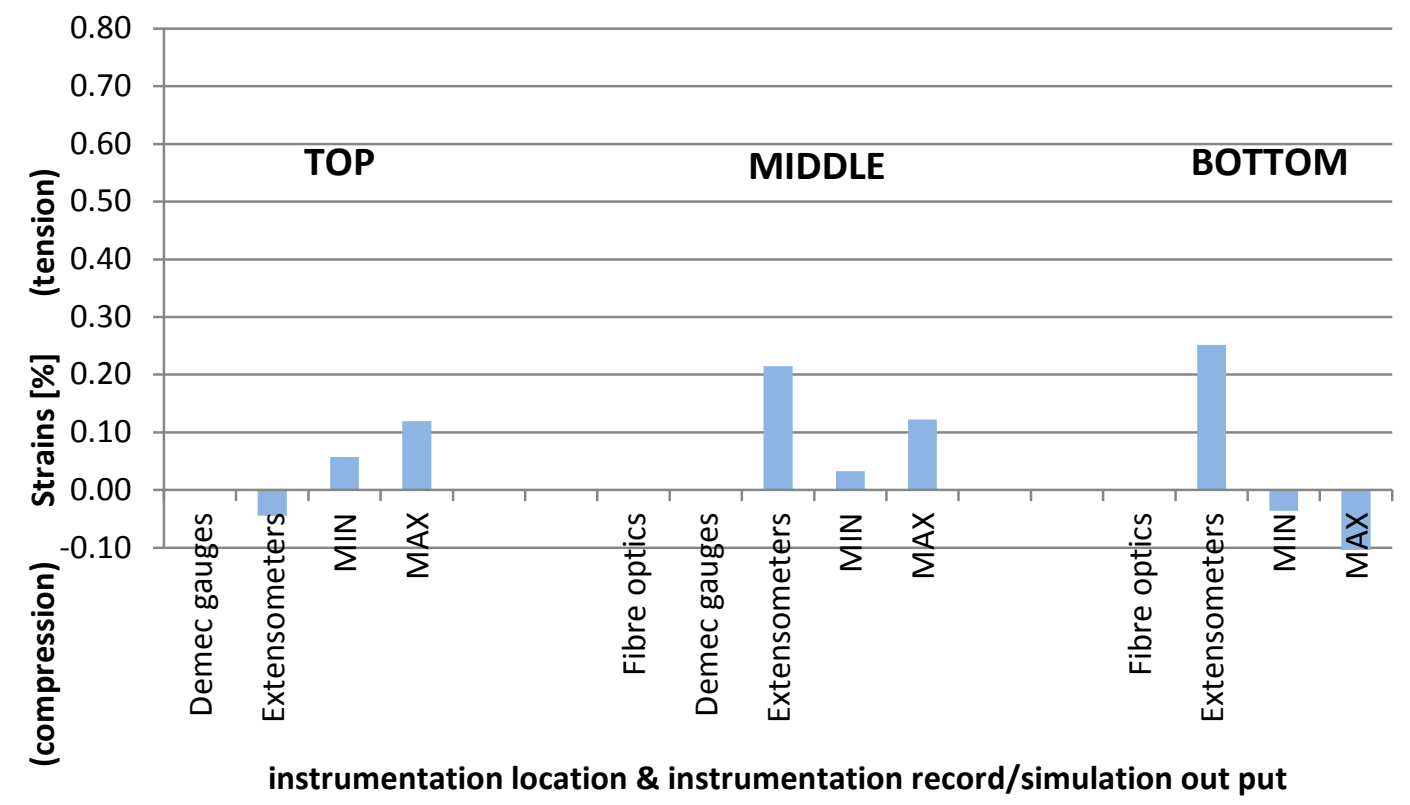


674 Figure 9. Temperatures measured on the top surface of the geomembrane, beneath the geotextile

\section{Temperature at the GMB surface}

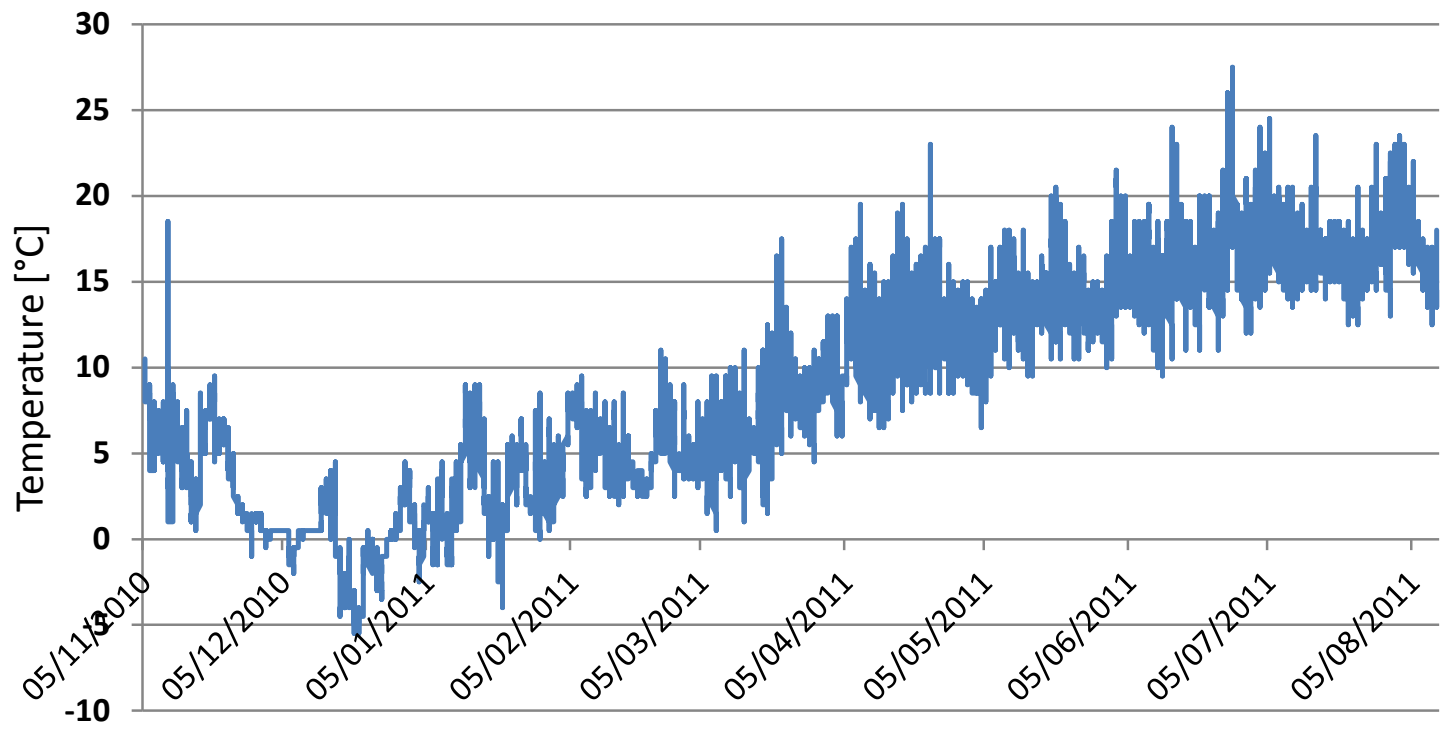

675 
676 Figure 10. Geomembrane Demec strain gauge measurements for locations at the top of and

677 across the slope.

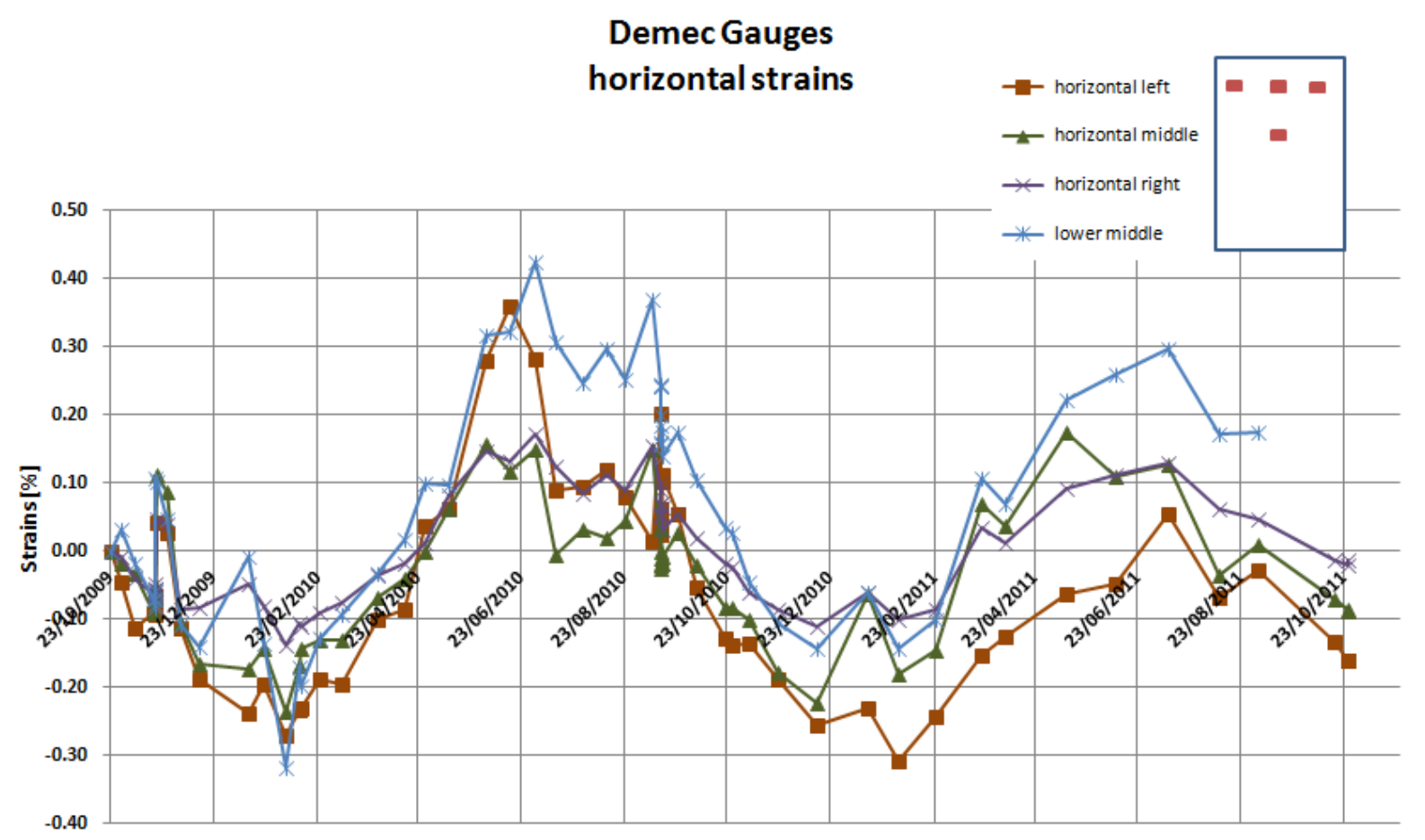

678

679 
680 Figure 11. Wrinkles in the geotextile with the contracted, planar, geomembrane beneath taken on

$68107 / 09 / 2010$.

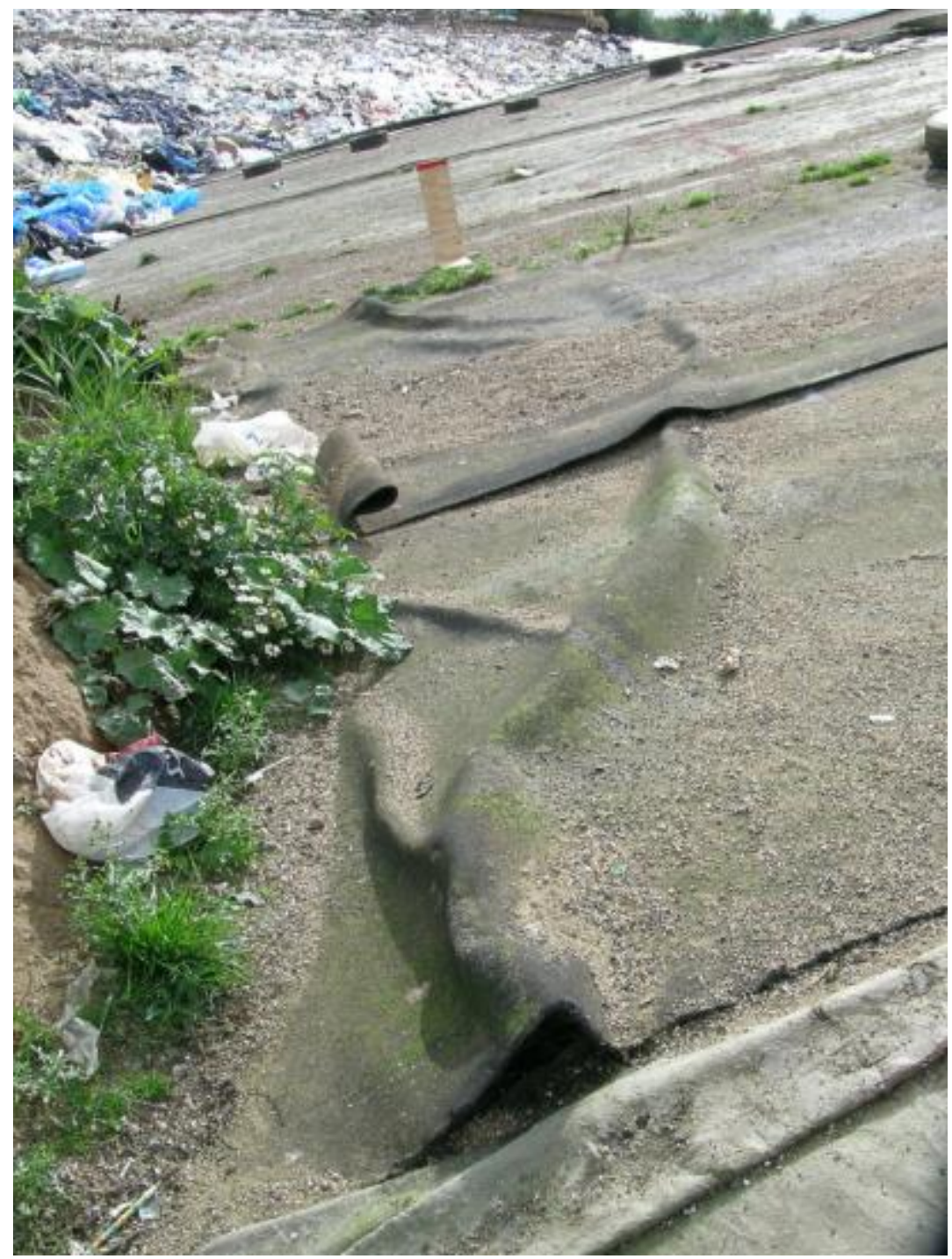

682

683

684 
685 Figure 12. Schematic geotextile deformation of exposed lining system in response to a cycle of 686 temperature

687

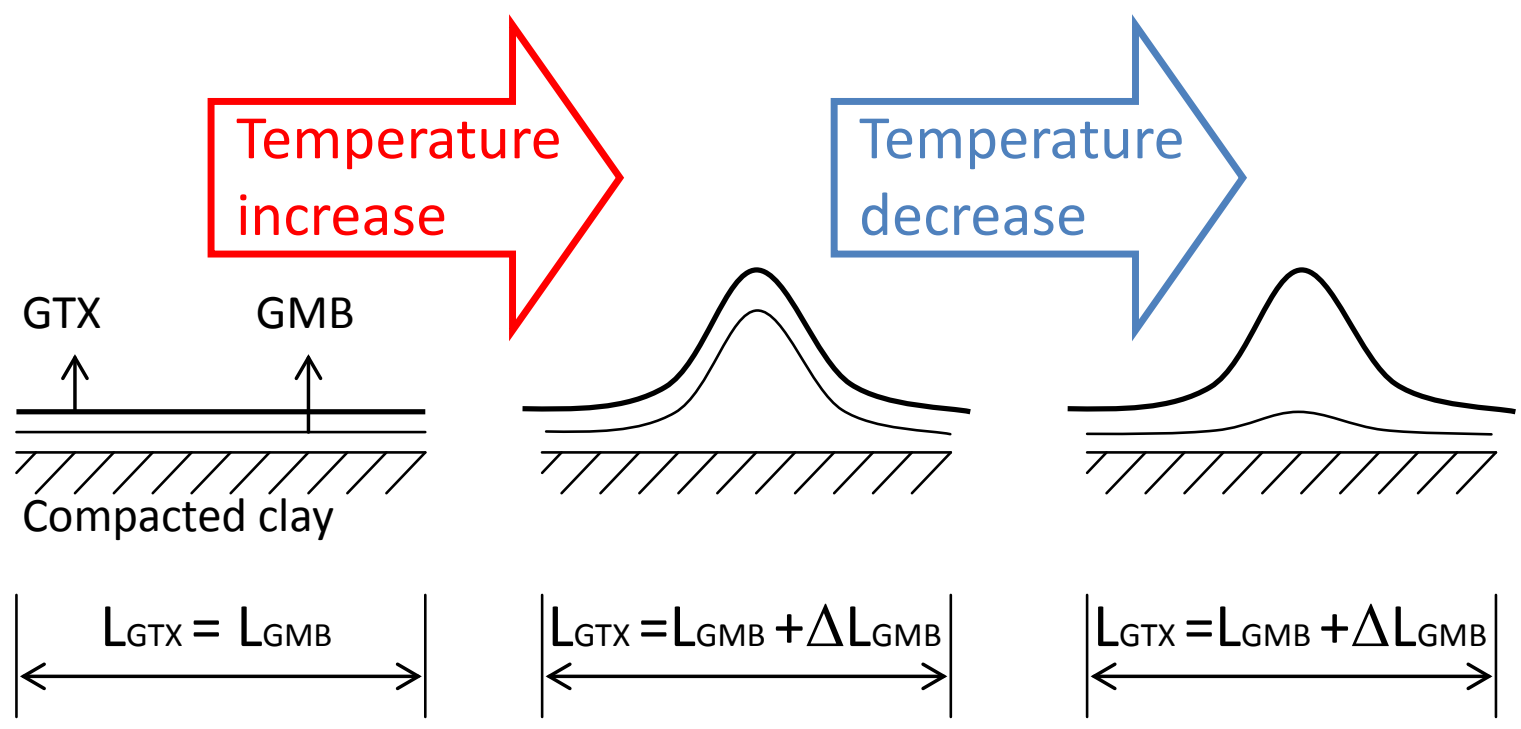

689 
Table 1. Instruments and parameters measured at Milegate Extension Landfill.

\begin{tabular}{|l|c|l|}
\hline \multicolumn{1}{|c|}{ Instrument } & $\begin{array}{c}\text { Number of } \\
\text { instruments } \\
\text { / sensors }\end{array}$ & \\
\hline $\begin{array}{l}\text { Vibrating Wire } \\
\text { Pressure Cells }\end{array}$ & 4 & Normal Stress \\
\hline Extensometers & 12 & $\begin{array}{l}\text { Displacement (at 6 points on the GM, } 6 \\
\text { on the GT) }\end{array}$ \\
\hline Demec strain gauges & 16 steel & GM strains across the slope \\
\cline { 2 - 3 } & disks & GM strains along the slope \\
\hline Fibre Optics & 15 & GM strains along the slope \\
\hline & 7 & GM temperature \\
\hline Thermistors & 2 & Clay surface temperature \\
\hline Additional records & & Waste height \\
\hline Temperature logger & 1 & GM temperature \\
\hline
\end{tabular}

Table 2. Material properties for FLAC model analysis.

\begin{tabular}{|c|c|c|c|c|c|c|c|}
\hline Material & Model & $\begin{array}{l}\text { Density } \\
\left(\mathrm{Mg} / \mathrm{m}^{3}\right)\end{array}$ & $\begin{array}{l}\varphi^{\prime} \\
\left(^{\circ}\right)\end{array}$ & $\begin{array}{c}c^{\prime} \\
(\mathbf{k P a})\end{array}$ & $\begin{array}{l}\text { Young's } \\
\text { Modulus } \\
\text { (MPa) }\end{array}$ & \multicolumn{2}{|c|}{$\begin{array}{c}\text { Poissof98 } \\
\text { Ratio } \\
699\end{array}$} \\
\hline Waste & $\begin{array}{l}\text { Mohr - } \\
\text { Coulomb }\end{array}$ & 1.0 & 25 & 5 & 0.5 & 0.3 & 700 \\
\hline $\begin{array}{l}\text { Sand } \\
\text { layer }\end{array}$ & $\begin{array}{l}\text { Mohr - } \\
\text { Coulomb }\end{array}$ & 1.7 & 35 & 0 & $\begin{array}{l}70 \\
20 *\end{array}$ & 0.4 & 701 \\
\hline Clay liner & $\begin{array}{l}\text { Mohr - } \\
\text { Coulomb }\end{array}$ & 1.7 & 23 & 5 & $\begin{array}{l}150 \\
50 *\end{array}$ & 0.3 & 702 \\
\hline
\end{tabular}

*altered values in further simulation (see Table 4 for details). 
Table 3. Interface properties used in modelling.

\begin{tabular}{|l|c|l|l|l|}
\hline Interface & $\begin{array}{l}\boldsymbol{\delta} \\
\mathbf{(}^{\circ} \\
\text { Peak/Residual }\end{array}$ & $\begin{array}{l}\boldsymbol{\alpha} \\
\mathbf{( k P a )} \\
\text { Peak/Residual }\end{array}$ & $\begin{array}{l}\text { Normal } \\
\text { stiffness } \\
(\mathbf{k P a} / \mathbf{m})\end{array}$ & $\begin{array}{l}\text { Shear } \\
\text { stiffness } \\
(\mathbf{k P a} / \mathbf{m})\end{array}$ \\
\hline Waste/sand & 20 & 5 & 10000 & 5000 \\
\hline $\begin{array}{l}\text { Sand/HPS } \\
\text { dry } \\
\text { wet }\end{array}$ & $29.9 / 29.6$ & $6.3 / 1.8$ & 10000 & 4500 \\
\hline HPS/HDPE & $29.6 / 29.9$ & $3.2 / 1.3$ & & \\
dry & $19.9 / 13.3$ & $2.3 / 1.4$ & & \\
wet & $20.8 / 14.7$ & $4.0 / 2.9$ & & \\
\hline $\begin{array}{l}\text { HDPE/Clay } \\
\text { drained }\end{array}$ & $22.0 / 22.0$ & $8.0 / 8.0$ & & \\
undrained & $31.1 / 25.1$ & $7.6 / 3.2$ & & \\
\hline
\end{tabular}

705 
707 strains

\begin{tabular}{|c|c|c|c|c|c|c|}
\hline \multicolumn{3}{|c|}{$\begin{array}{l}\text { IN-PUT VALUES } \\
\text { COMBINATIONS }\end{array}$} & \multicolumn{4}{|c|}{ RESULTS } \\
\hline $\begin{array}{c}\text { Applied } \\
\text { interface } \\
\text { shear } \\
\text { strength }\end{array}$ & $\begin{array}{c}\text { Clay } \\
\text { Stiffness } \\
\text { [MPa] }\end{array}$ & $\begin{array}{c}\text { Soil/Geote } \\
\text { xtile } \\
\text { Stiffness } \\
\text { [MPa] }\end{array}$ & $\begin{array}{c}\text { Geotextile Max } \\
\text { Displacements } \\
\text { [mm] }\end{array}$ & $\begin{array}{c}\text { Geomembrane } \\
\text { Max } \\
\text { Displacements } \\
\text { [mm] }\end{array}$ & $\begin{array}{c}\text { Geomemb } \\
\text { rane Max } \\
\text { Strains } \\
\text { [\%] }\end{array}$ & $\begin{array}{c}\text { Geomembr } \\
\text { ane Max } \\
\text { Axial } \\
\text { Forces } \\
\text { [kN/m] } \\
\end{array}$ \\
\hline Peak & \multirow[b]{2}{*}{150} & \multirow[b]{2}{*}{ 70/1.2 } & 30.5 & 20.1 & 0.13 & 1.13 \\
\hline $\begin{array}{c}\text { Strain } \\
\text { Softening }\end{array}$ & & & 35.3 & 20.7 & 0.18 & 1.59 \\
\hline $\begin{array}{c}\text { Reduced } \\
\text { values }\end{array}$ & 50 & $20 / 1.8$ & 92.0 & 40.9 & 0.26 & 2.29 \\
\hline \multicolumn{3}{|c|}{ Measuring instruments } & \multicolumn{4}{|c|}{ Monitored values } \\
\hline \multicolumn{3}{|c|}{ Extensometers readings } & 83.5 & 25.9 & 0.26 & 1.76 \\
\hline \multicolumn{3}{|c|}{ Demec gauge slope direction* } & - & - & 0.31 & 2.09 \\
\hline \multicolumn{3}{|c|}{$\begin{array}{r}\text { Demec gauge across slope } \\
\text { direction* }\end{array}$} & - & - & 0.42 & 2.83 \\
\hline \multicolumn{3}{|c|}{ Fibre optic readings* } & - & - & 0.78 & 5.27 \\
\hline
\end{tabular}

709 *Demec gauge and Fibre optic readings are suspected to be mostly temperature related; this is

710 based on the time when the readings were collected and section on the slope where the reported 711 peak occurred. 
712 Table 5. Deformation of the geotextile during placement of the $2^{\text {nd }}$ sand veneer obtained from 713 extensometer readings compared to theoretical elongation of the geomembrane sheet for the 714 exposed section. Theoretical elongation are calculated for the lower boundary assuming

$715 \Delta \mathrm{T}=30^{\circ} \mathrm{C}$ and coefficient of thermal expansion equal $1.1 \times 10^{-4} \mathrm{~cm} / \mathrm{cm} /{ }^{\circ} \mathrm{C}$, and higher boundary $716 \Delta \mathrm{T}=40^{\circ} \mathrm{C}$ and coefficient of thermal expansion equal $1.5 \times 10^{-4} \mathrm{~cm} / \mathrm{cm} /{ }^{\circ} \mathrm{C}$.

\begin{tabular}{|l|l|l|l|}
\hline Sensor ID & $\begin{array}{l}\text { Sensor } \\
\text { location below } \\
\text { the crest / } \\
\text { When covered } \\
\text { by the sand } \\
\text { layer }\end{array}$ & $\begin{array}{l}\text { Monitored geotextile } \\
\text { displacement during } \\
\text { placement of the } 2^{\text {nd }} \text { sand } \\
\text { veneer }\end{array}$ & $\begin{array}{l}\text { Theoretical } \\
\text { geomembrane elongation } \\
\text { due to temp. change for the } \\
\text { exposed HDPE sheet } \\
\text { length }\end{array}$ \\
\hline Ext.1 & $\begin{array}{l}3.0 \mathrm{~m} \\
1 \text { st veneer }\end{array}$ & $20 \mathrm{~mm}$ & $9.9-18.0 \mathrm{~mm}$ \\
\hline Ext.2 & $\begin{array}{l}8.4 \mathrm{~m} \\
2^{\text {nd }} \text { veneer }\end{array}$ & $50 \mathrm{~mm}$ & $27.7-50.4 \mathrm{~mm}$ \\
\hline Ext.3 & $\begin{array}{l}13.8 \mathrm{~m} \\
3^{\text {rd }} \text { veneer }\end{array}$ & $80 \mathrm{~mm}$ & $45.5-82.8 \mathrm{~mm}$ \\
\hline
\end{tabular}

